\title{
9. GEOCHEMISTRY OF HYDROTHERMALLY ALTERED BASALTS: DEEP SEA DRILLING PROJECT HOLE 504B, LEG 831
}

\author{
Jeffrey C. Alt, Department of Marine Geology and Geophysics, Rosenstiel School of Marine and Atmospheric \\ Science, University of Miami \\ and \\ Rolf Emmermann, Mineralogisch-Petrologisches Institut, Universitat Giessen ${ }^{2}$
}

\begin{abstract}
This chapter documents the chemical changes produced by hydrothermal alteration of basalts drilled on Leg 83 , in Hole 504B. It interprets these chemical changes in terms of mineralogical changes and alteration processes and discusses implications for geochemical cycling.

Alteration of Leg 83 basalts is characterized by nonequilibrium and is heterogeneous on a scale of centimeters to tens or hundreds of meters. The basalts exhibit trends toward losses of $\mathrm{SiO}_{2}, \mathrm{CaO}, \mathrm{TiO}_{2}$; decreases in density; gains of $\mathrm{MnO}, \mathrm{Na}_{2} \mathrm{O}, \mathrm{CO}_{2}, \mathrm{H}_{2} \mathrm{O}^{+}$, S; slight gains of $\mathrm{MgO}$; increased oxidation of Fe; and variable changes in $\mathrm{Al}_{2} \mathrm{O}_{3}$. Some mobility of rare earth elements (REE) also occurred, especially the light REE and Eu. The basalts have lost Ca in excess of $\mathrm{Mg}+\mathrm{Na}$ gains. Variations in chemical trends are due to differing water/rock ratios, substrate control of secondary mineralogy, and superimposition of greenschist and zeolite facies mineralogies. Zeolitization resulted in uptake of Ca and $\mathrm{H}_{2} \mathrm{O}$ and losses of $\mathrm{Si}, \mathrm{Al}$, and $\mathrm{Na}$. These effects are different from the $\mathrm{Na}$ uptake observed in other altered basalts from the seafloor attributed to the zeolite facies and are probably due to higher temperatures of alteration of Leg 83 basalts.

Basalts from the transition zone are enriched in $\mathrm{Mn}, \mathrm{S}$, and $\mathrm{CO}_{2}$ relative to the pillow and dike sections and contain a metal-sulfide-rich stockwork zone, suggesting that they once were located within or near a hydrothermal upflow zone. Samples from the bottom of the dike section are extensively fractured and recrystallized indicating that alteration was significantly affected by local variations in permeability.
\end{abstract}

\section{INTRODUCTION}

Alteration of the oceanic crust in submarine hydrothermal systems has been suggested to play a significant role in geochemical cycling of elements in the oceans (e.g., Humphris and Thompson, 1978; Edmond et al., 1979). Leg 83 of the Deep Sea Drilling Project has deepened Hole 504B, drilled previously on Legs 69 and 70, to over $1 \mathrm{~km}$ into basement. The hole penetrated into a sheeted dike complex, and the first in situ basalts containing greenschist facies mineral parageneses were recovered from the oceanic crust. These cores thus provide a unique set of samples from which to study the chemical effects of hydrothermal alteration of the crust.

A detailed description of alteration mineralogy and interpreted conditions of alteration are given elsewhere (Alt et al., this volume). The purpose of this chapter is to document the chemical changes produced by hydrothermal alteration of Leg 83 basalts, to interpret these chemical changes in terms of mineralogical changes and alteration processes, and to discuss implications for geochemical cycling.

\footnotetext{
${ }^{1}$ Anderson, R. N., Honnorez, J., Becker, K., et al., Init. Repts. DSDP, 83: Washington (U.S. Govt. Printing Office).

2 Addresses: (Alt, present address) Department of Earth and Planetary Sciences, Washington University, Campus Box 1169, St. Louis, MO 63130; (Emmermann) Mineralogisch-Petrologisches Institut, Universität Giessen, Senckenbergstrasse 3, D-6300 Giessen, Federal Republic of Germany.
}

\section{Site 504}

DSDP Site 504 is located in 5.9-m.y.-old crust south of the Costa Rica Rift in the eastern Pacific. The hole reaches $1.35 \mathrm{~km}$ into the oceanic crust, penetrating $274.5 \mathrm{~m}$ of sediment; $571.5 \mathrm{~m}$ of pillow and massive basalts and breccias; a 209-m transition zone composed of pillows, massive flows, and dikes; and $295 \mathrm{~m}$ of dikes and massive units that are interpreted to be part of a sheeted dike complex. The Leg 69 and 70 sections penetrated through the sediment and $561.5 \mathrm{~m}$ into basement. The Leg 83 section discussed in this chapter begins at $836 \mathrm{~m}$ below seafloor and consists of the lowermost 10 $\mathrm{m}$ of pillow basalts, plus the transition zone and dike sections. Details of the lithostratigraphy are given in Cann, Langseth, Honnorez, Von Herzen, White, et al. (1983) and Adamson (this volume). Measured heat flow at the site falls close to the theoretical conductive cooling curve for ocean crust, and temperatures in the hole fall on a conductive gradient ranging from $60^{\circ} \mathrm{C}$ at the basement/sediment interface to $160^{\circ} \mathrm{C}$ at the bottom of the hole (Becker et al., this volume).

The chemistry of Leg 69 and 70 pillow sections is given in Cann, Langseth, Honnorez, Von Herzen, White, et al. (1983). Basalts from 274.5 to $584.5 \mathrm{~m}$ are characterized by the presence of red iron hydroxide-rich oxidation halos and by hydration, oxidation of iron, gain of $\mathrm{K}$, loss of $\mathrm{S}$, and variable $\mathrm{CO}_{2}$ contents because of the reaction of the basalts with oxygenated seawater. From 584.5 to $836 \mathrm{~m}$ the basalts are characterized by generally 
little chemical change. The basalts are hydrated, with possible slight $\mathrm{Ca}$ and $\mathrm{Al}$ losses and $\mathrm{Mg}$ gains that are due either to reaction with seawater at low water/rock ratios or with seawater that had previously reacted with basalt.

\section{Alteration of Leg 83 Basalts}

Alteration of Leg 83 basalts is described in detail by Alt et al. (this volume) and is only very briefly summarized in this chapter. The rocks are generally characterized by incomplete replacement of primary phases, although they may be locally totally recrystallized. From 836 to $898 \mathrm{~m}$ the basalts are uniformly dark gray in color and contain smectite-chlorite mixtures as the major alteration phase. From $898 \mathrm{~m}$ to the bottom of the hole greenschist-and zeolite-facies mineralogies are present in varying amounts. Olivine is replaced by chlorite, chlorite-smectite mixtures, and pyrite; plagioclase is partly replaced by albite, heulandite, laumontite, and minor scolecite; clinopyroxene is partly replaced by actinolite and magnetite; and titanomagnetite is partly to totally replaced by sphene. The rocks below $898 \mathrm{~m}$ are generally dark gray with centimeter-sized, light gray or greenish, more extensively altered wall rock zones around veins and vugs.

Alteration of the Leg 83 basalts is interpreted to have taken place in a generally evolving and cooling hydrothermal system (Alt et al., this volume; Honnorez et al., this volume). Three basic stages of alteration have been determined: (1) formation of chlorite, actinolite, albite, sphene, pyrite, and minor quartz in veins and host rocks by reaction of basalts with partially reacted seawater (Mg-bearing, locally metal- and Si-enriched) at temperatures of at least $200-250^{\circ} \mathrm{C}$; followed by (2) formation of quartz, epidote, and sulfides in veins from relatively evolved (Mg-depleted, metal- and Si-enriched, and possibly ${ }^{18} \mathrm{O}$-enriched) seawater-derived solutions at temperatures of up to $380^{\circ} \mathrm{C}$; and finally by (3) zeolite and calcite formation from evolved fluids (Mg-depleted, $\mathrm{Ca}$ and ${ }^{18} \mathrm{O}$-enriched) at temperatures of up to $250^{\circ} \mathrm{C}$.

\section{SAMPLING AND METHODS}

Samples were selected from throughout the Leg 83 section and include light gray wall rock alteration zones and adjacent dark gray host rocks for comparison (Table 1). Samples were generally selected to be free of veins containing secondary minerals, but two dike margin breccias with abundant clay mineral veins (Table 1, Analyses 24, 25) and one clay-rich brecciated massive basalt (Table 1, Analysis 3 ) were also sampled. Altered glass from a pillow rim was sampled to compare with the alteration of the adjacent crystalline basalt (Table 1, Analysis $10)$.

Major and trace elements were determined by X-ray fluorescence carried out on glass beads fused with lithium metaborate (rock/flux ratio of 1:4) using a Philips $\mathrm{PW} 1400$ spectrometer, $\mathrm{H}_{2} \mathrm{O}^{+}$was measured by Karl Fischer titration after thermal decomposition of the rock, and $\mathrm{Fe}^{2+}$ was determined by manganometric titration. A coulometric titration apparatus was used for the determination of $\mathrm{CO}_{2}$ and S. Sulfur concentrations above $0.2 \%$ were calculated as $\mathrm{FeS}_{2}$ and are listed among the major components. Sulfur concentrations less than $0.2 \%$ are given as S (wt.\%) separately. Rare earth elements (REE) were analyzed by inductively coupled plasma emission spectroscopy (Emmermann, this volume). Densities were determined by weighing the samples in air after drying at $110^{\circ} \mathrm{C}$ for $48 \mathrm{hr}$. followed by weighing in distilled water to determine volumes. Analyses of basalt standards and Leg 83 interlaboratory standards are given in Table 2. Ana- lytical uncertainty for density measurements determined by repeated measurements of standards is $\pm 1 \%$.

\section{CHEMICAL CHANGES}

In considering chemical changes during metamorphism, chemical analyses are often normalized to constant $\mathrm{Ti}, \mathrm{Zr}$, Y, or occasionally $\mathrm{Al}$, which are considered to be immobile elements, in order to take into account dilution effects or changes in density. At present, we do not have data for $\mathrm{Zr}$ and $\mathrm{Y}$, and $\mathrm{Ti}$ and $\mathrm{Al}$ were not always conserved during alteration of Leg 83 basalts. Bulk rock compositions were recalculated as moles per cubic centimeter, but this did not significantly affect the observed chemical trends. Thus, most of the following discussion is based on oxide weight percentages.

One of the difficulties in determining chemical changes for altered rocks is in finding a reliable unaltered rock composition for comparison. All of the basalts recovered from Hole 504B are mineralogically and chemically altered to some extent (Honnorez et al., 1983; Hubberten et al., 1983; Alt et al., this volume); however, unaltered basaltic glass is common in the Leg 69 and 70 pillow section of the hole. Although the primary composition of the Hole 504B section is relatively uniform (with the exception of a few "anomalous" high P and Ti units; Hubberten et al., 1983; Emmermann, this volume), 13 different glass compositional types have been identified from the pillow section (Natland et al., 1983) indicating that significant compositional variations do occur. The means and standard deviations of 51 glass analyses and of 58 least-altered basalts from Leg 69 and 70 sections of the hole (both excluding the "anomalous" high $\mathrm{P}$ and Ti units) are presented in Table 3. The two means are very similar and are statistically indistinguishable at the $99.5 \%$ confidence level. Based on the close similarity of the mean fresh glass and least-altered basalt compositions in Table 3 and the relative uniformity of bulk rock compositions among the Leg 69,70 , and $83 \mathrm{sec}-$ tions in the hole, the average glass composition in Table 3 is used in this chapter as the unaltered basalt composition for Hole 504B, thus providing a basis for determining chemical changes arising from hydrothermal alteration. This average does not include the few "anomalous" high $\mathrm{P}$ and Ti units, since these units were not sampled for the present study. It should be pointed out, however, that the glass composition in Table 3 is an $a v$ erage, and that the primary composition of individual bulk rock samples could deviate from these values, leading to errors in the chemical changes determined to be due to hydrothermal alteration. The bulk rock composition of a crystalline pillow interior could also differ significantly from that of the glass at the corresponding rim of the same pillow because of phenocryst accumulation (e.g., Staudigel et al., 1979). However, since we are using the mean glass composition (which is nearly identical to the average least-altered basalt composition) individual glass-whole rock variations should not affect the discussion.

Bulk rock compositions are plotted versus depth in Figure 1, along with the average unaltered glass composition from Table 3 for comparison. Relative to the glass 
Table 1. Bulk rock analyses of altered basalts, Hole 504B.

\begin{tabular}{|c|c|c|c|c|c|c|c|c|c|c|c|c|c|c|c|c|c|c|c|c|c|c|c|c|c|c|c|c|}
\hline $\begin{array}{l}\text { Core-Section } \\
\text { (interval in cm) }\end{array}$ & $\begin{array}{l}\text { Rock } \\
\text { type }\end{array}$ & Analysis & $\mathrm{SiO}_{2}$ & $\mathrm{TiO}_{2}$ & $\mathrm{Al}_{2} \mathrm{O}_{3}$ & $\mathrm{FeO}$ & $\mathrm{Fe}_{2} \mathrm{O}_{3}$ & $\mathrm{MnO}$ & $\mathrm{MgO}$ & $\mathrm{CaO}$ & $\mathrm{Na}_{2} \mathrm{O}$ & $\mathrm{K}_{2} \mathrm{O}$ & $\mathrm{P}_{2} \mathrm{O}_{5}$ & $\mathrm{H}_{2} \mathrm{O}^{+}$ & $\mathrm{CO}_{2}$ & $\mathrm{FeS}_{2}$ & Total & $\mathrm{Fe}_{2} \mathrm{O}_{3}{ }^{\mathrm{T}}$ & $\mathrm{H}_{2} \mathrm{O}^{-}$ & $\mathrm{Ni}$ & $\mathrm{Zn}$ & s & $\mathrm{Cr}$ & Co & $\mathrm{Cu}$ & $\mathrm{Ga}$ & $\begin{array}{l}\text { Density } \\
\left(\mathrm{g} / \mathrm{cm}^{3}\right)\end{array}$ & $\begin{array}{c}\text { Depth } \\
\text { (m) }\end{array}$ \\
\hline $72-2,126-129$ & d & 1 & 49.00 & 0.85 & 16.00 & 2.91 & 5.46 & 0.16 & 8.75 & 13.00 & 1.89 & 0.02 & 0.06 & 1.88 & 0.49 & 0.00 & 100.47 & 8.98 & 1.52 & & & 0.03 & & & & & 2.81 & 846.3 \\
\hline $76-1,65-68$ & d & 2 & 48.50 & 0.92 & 16.40 & 3.78 & 5.28 & 0.17 & 7.88 & 12.70 & 2.04 & 0.02 & 0.06 & 2.36 & 0.26 & 0.00 & 100.37 & 9.65 & 1.26 & & & 0.10 & & & & & 2.84 & 880.2 \\
\hline $78-1,102-106$ & b & 3 & 49.60 & 0.92 & 14.40 & 1.70 & 5.99 & 0.19 & 9.68 & 10.40 & 3.01 & 0.03 & 0.07 & 2.41 & 0.17 & 1.59 & 100.16 & 9.42 & 0.51 & & & 1.70 & & & & & 2.74 & 898.5 \\
\hline $79-2,62-66$ & 1 & 4 & 49.00 & 0.91 & 15.80 & 2.57 & 5.36 & 0.15 & 9.03 & 12.10 & 2.16 & 0.02 & 0.06 & 2.66 & 0.19 & 0.00 & 100.01 & 8.53 & 0.76 & & & 0.09 & & & & & 2.78 & 906.6 \\
\hline $79-3,147-149$ & 1 & 5 & 47.40 & 0.91 & 15.90 & 1.63 & 5.12 & 0.22 & 7.85 & 11.90 & 2.47 & 0.02 & 0.06 & 2.18 & 0.23 & 3.72 & 99.61 & 9.80 & 0.42 & & & 3.97 & & & & & 2.80 & 909.0 \\
\hline $80-1,33-37$ & 1 & 6 & 47.50 & 0.85 & 16.90 & 1.40 & 5.48 & 0.33 & 7.93 & 11.60 & 2.43 & 0.02 & 0.05 & 3.14 & 0.12 & 2.21 & 39.96 & 8.96 & 0.52 & & & 2.36 & & & & & 2.63 & 910.3 \\
\hline $80-2,63-67$ & 1 & 7 & 47.40 & 0.90 & 17.10 & 1.63 & 5.12 & 0.33 & 6.42 & 10.00 & 3.05 & 0.02 & 0.06 & 3.97 & 0.20 & 4.00 & 100.20 & 9.98 & 0.82 & 150 & 98 & 4.27 & 397 & 42 & 93 & 15 & 2.46 & 912.2 \\
\hline $80-3,124-133$ & 1 & 8 & 48.10 & 0.84 & 17.10 & 1.99 & 5.21 & 0.27 & 7.08 & 13.00 & 2.42 & 0.02 & 0.05 & 2.26 & 0.19 & 1.35 & 99.88 & 8.68 & 0.67 & & & 1.44 & & & & & 2.68 & 914.2 \\
\hline $81-1,83-86$ & 1 & 9 & 50.20 & 0.92 & 14.30 & 2.06 & 5.88 & 0.31 & 8.08 & 10.90 & 3.14 & 0.03 & 0.05 & 2.90 & 0.29 & 1.14 & 100.20 & 9.34 & 0.67 & & & 1.22 & & & & & 2.68 & 920.4 \\
\hline $81-1,83-86$ & $\mathrm{~g}$ & 10 & 35.70 & 1.01 & 18.00 & 4.03 & 10.61 & 0.43 & 15.70 & 3.22 & 1.58 & 0.03 & 0.07 & 9.52 & 0.36 & 0.00 & 100.26 & 15.80 & 1.63 & & & 0.03 & & & & & 2.51 & 920.4 \\
\hline $82-1,68-73$ & 1 & 11 & 48.90 & 0.89 & 15.40 & 1.77 & 6.47 & 0.23 & 8.49 & 12.40 & 1.82 & 0.02 & 0.07 & 1.87 & 0.24 & 0.97 & 99.54 & 9.60 & 0.29 & & & 1.04 & & & & & 2.92 & 929.2 \\
\hline $82-1,68-73$ & $d$ & 12 & $\begin{array}{l}49.30 \\
49.30\end{array}$ & 0.92 & $\begin{array}{l}15.40 \\
14.50\end{array}$ & 2.29 & $\begin{array}{l}6.86 \\
463\end{array}$ & 0.25 & $\begin{array}{l}8.66 \\
6.55\end{array}$ & 12.40 & 1.67 & 0.02 & 0.06 & 2.01 & 0.22 & 0.00 & 100.06 & 9.91 & 0.38 & & & 0.09 & & & & & 2.92 & $\begin{array}{l}929.2 \\
929.4\end{array}$ \\
\hline $\begin{array}{l}82-1,90-96 \\
84-2,48-50\end{array}$ & 1 & 13 & $\begin{array}{l}49.30 \\
45.10\end{array}$ & 0.99 & $\begin{array}{l}14.50 \\
13.50\end{array}$ & 1.52 & $\begin{array}{l}4.63 \\
577\end{array}$ & 0.37 & $\begin{array}{l}6.55 \\
8.32\end{array}$ & 8.73 & 3.92 & 0.04 & 0.06 & $\begin{array}{l}3.21 \\
5.30\end{array}$ & 0.48 & 5.74 & 100.04 & $\begin{array}{r}10.40 \\
9.53\end{array}$ & 0.98 & & & 6.13 & & & & & 2.66 & $\begin{array}{l}929.4 \\
948.5\end{array}$ \\
\hline $\begin{array}{l}84-2,48-50 \\
87-1,116-123\end{array}$ & 1 & 14 & $\begin{array}{l}51.10 \\
48.99\end{array}$ & $\begin{array}{l}0.98 \\
0.98\end{array}$ & $\begin{array}{l}13.50 \\
14.70\end{array}$ & 1.82 & 5.77 & 0.27 & $\begin{array}{l}8.32 \\
8.38\end{array}$ & 8.24 & 2.72 & 0.02 & 0.07 & $\begin{array}{r}5.30 \\
2.38\end{array}$ & 0.25 & 1.96 & $\begin{array}{l}100.32 \\
100.27\end{array}$ & $\begin{array}{r}9.53 \\
10.30\end{array}$ & $\begin{array}{l}1.05 \\
0.30\end{array}$ & & & $\begin{array}{l}2.10 \\
0.04\end{array}$ & & & & & 2.56 & $\begin{array}{l}948.5 \\
968.2\end{array}$ \\
\hline $91-1,66-70$ & 1 & 16 & $\begin{array}{l}48.90 \\
52.40\end{array}$ & $\begin{array}{l}0.98 \\
0.88\end{array}$ & $\begin{array}{l}14.10 \\
13.10\end{array}$ & 2.39 & $\begin{array}{l}.7 .51 \\
5.76\end{array}$ & $\begin{array}{l}0.30 \\
0.29\end{array}$ & $\begin{array}{l}8.38 \\
7.91\end{array}$ & $\begin{array}{l}12.60 \\
8.32\end{array}$ & $\begin{array}{l}2.23 \\
3.81\end{array}$ & $\begin{array}{l}0.02 \\
0.02\end{array}$ & 0.0 & $\begin{array}{l}2.38 \\
3.93\end{array}$ & $\begin{array}{l}0.20 \\
0.26\end{array}$ & $\begin{array}{l}.000 \\
0.49\end{array}$ & $\begin{array}{r}90.27 \\
99.62\end{array}$ & $\begin{array}{r}10.30 \\
9.11\end{array}$ & $\begin{array}{l}0.30 \\
1.30\end{array}$ & & & $\begin{array}{l}0.04 \\
0.52\end{array}$ & & & & & $\begin{array}{l}2.80 \\
2.51\end{array}$ & $\begin{array}{l}9008.2 \\
1004.2\end{array}$ \\
\hline $91-1,66-70$ & d & 17 & 50.00 & 0.74 & 15.30 & 2.17 & 6.86 & 0.20 & 9.12 & 12.90 & 1.64 & 0.02 & 0.0 & 1.24 & 0.22 & 0.00 & 100.47 & 9.79 & 0.38 & & & 0.10 & & & & & 2.99 & 1004.2 \\
\hline $94-1,13$ & d & 18 & 49.20 & 0.96 & 15.40 & 2.09 & 6.75 & 0.21 & 8.48 & 12.00 & 2.15 & & 0.0 & & 0.19 & & 100.51 & 10.00 & 0.51 & & & 0.72 & & & & & 92 & 1031.8 \\
\hline $95-1,140-143$ & 1 & 19 & 50.70 & 0.99 & 14.30 & 1.91 & 7.41 & 0.20 & 7.86 & 12.10 & 2.02 & 0.02 & 0.07 & 2.01 & 0.23 & 0.00 & 99.82 & 10.10 & 0.22 & & & 0.04 & & & & & 2.91 & 1040.9 \\
\hline $97-1,82-$ & d & 20 & 49.40 & 0.93 & 14.70 & 2.51 & 7.10 & 21 & 8.57 & 12.50 & 2.29 & 0.02 & 0.07 & 1.80 & 0.09 & 0.00 & 100.19 & 10.40 & 0.40 & & & 0.11 & & & & & 2.95 & 1058.3 \\
\hline $97-1,88-90$ & 1 & 21 & 46.70 & 0.88 & 12.50 & 2.16 & 6.15 & 21 & 9.01 & 13.30 & 0.57 & & 0.06 & 6.70 & 0.43 & 1.53 & 100.23 & 10.00 & 1.16 & & & 1.64 & & & & & 61 & 1058.4 \\
\hline $99-1,70-74$ & 1 & 22 & 48.40 & 0.90 & 13.40 & 2.36 & 8.53 & 23 & 8.41 & 10.10 & 2.74 & 0.02 & 0.06 & 4.89 & 0.12 & 0.00 & 100.16 & 11.80 & 0.41 & & & 0.03 & & & & & 69 & 1072.2 \\
\hline $99-2,42-50$ & 1 & 23 & 47.00 & 0.98 & 14.50 & 2.85 & 10.06 & 25 & 8.36 & 7.47 & 3.46 & & 0.06 & 5.07 & 0.15 & 0.00 & 100.24 & 14.00 & 0.83 & & & 0.01 & & & & & 70 & 1073.5 \\
\hline $100-1,83-87$ & b & 24 & 50.20 & 0.89 & 13.20 & 2.45 & 8.98 & 0.22 & 7.78 & 7.61 & 2.95 & & 0.07 & 5.73 & 0.09 & 0.00 & 100.20 & 12.40 & 1.05 & & & 0.06 & & & & & 2.60 & 1081.4 \\
\hline $101-1,134-138$ & $\mathrm{~b}$ & 25 & 50.00 & 0.91 & 13.90 & 2.58 & 7.22 & 0.21 & 8.01 & 10.60 & 3.39 & & 0.06 & 3.09 & 0.09 & 0.00 & 100.09 & 10.60 & 0.64 & & & 0.05 & & & & & 2.82 & 1090.9 \\
\hline $104-2,57-61$ & 1 & 26 & 50.00 & 0.57 & 17.10 & 1.78 & 5.38 & 0.14 & 7.73 & 12.40 & 2.57 & 0. & 0.04 & 2.27 & 0.09 & 0.00 & 100.10 & 7.76 & 0.37 & 85 & 54 & 0.01 & 304 & 33 & 10 & 14 & $2.88^{\mathrm{a}}$ & 1118.5 \\
\hline $104-2,61-65$ & d & 27 & 49.10 & 0.94 & 16.60 & 2.96 & 6.19 & 17 & 7.72 & 12.90 & 2.01 & 0. & 0.07 & 1.58 & 0.10 & 0.00 & 100.36 & 9.84 & 0.38 & 96 & 68 & 0.07 & 338 & 43 & 64 & 16 & $2.93^{\mathrm{a}}$ & 1118.6 \\
\hline $104-2,67-72$ & d & 28 & 49.10 & 0.84 & 16.30 & 2.18 & 6.30 & & 8.18 & 12.70 & 2.03 & 0. & 0.06 & 2.21 & 0.09 & 0.00 & 100.17 & 9.18 & 0.48 & 104 & 66 & 0.03 & 342 & 37 & 50 & 16 & $2.88^{\mathrm{a}}$ & 1118.7 \\
\hline $104-2,79-82$ & d & 29 & 48.10 & 0. & 16.40 & 2.89 & 6.37 & & 8.48 & 12.80 & 1.8 & 0. & 0.0 & 2.21 & 0.09 & 0.00 & 100.38 & 9.97 & 0.67 & 154 & 66 & 0.09 & 414 & 45 & 64 & 15 & $2.88^{\mathrm{a}}$ & 1118.8 \\
\hline $107-1,90-92$ & 1 & 30 & 50.10 & & 14.80 & 2.64 & 6.45 & & 8. & 13. & 2.0 & 0. & 0. & 1.4 & 0.09 & 0.00 & 100.39 & 9.8 & 0.53 & 90 & 72 & 0.08 & 293 & 39 & 89 & 15 & & 1144.4 \\
\hline $111-1,41$ & d & 31 & & & & 3.43 & 6.23 & & & 12.1 & 1.9 & & 0. & 3. & & 0.00 & 99.50 & 10.30 & 91 & 275 & 75 & 0.03 & 529 & 57 & 101 & 15 & & 1161.9 \\
\hline & 1 & 32 & & & & 2.0 & 6. & & & 12. & 1.8 & & 0. & & 0.1 & & 100.27 & 9. & 0.47 & 127 & 72 & 0.05 & 344 & 39 & 76 & 14 & & 1171.5 \\
\hline 117. & 1 & 33 & & & & 2.8 & 9.76 & & & 7. & & & 0. & 5. & 0.1 & 0.00 & 100.34 & 13. & 0.85 & & & 0.03 & & & & & & 1189.8 \\
\hline & 1 & 34 & & & & 1.5 & 7. & & & 10 & & & & & & & & 10. & & 84 & 90 & 0.03 & 242 & 41 & 53 & 15 & & 1208.2 \\
\hline & d & 3. & & & & 2.7 & & & & & 2. & & & & & & & 10. & & 86 & 93 & 0.05 & 235 & 43 & 55 & 16 & & 1224.6 \\
\hline & d & 36 & & & & & & & & & & & & & & & & 9. & & 153 & 67 & 0.08 & 384 & 46 & 85 & 15 & & 1254.6 \\
\hline & 1 & 3 & & & & & & & & & & & & & & & & & & & & 0.03 & & & & & & 1296.2 \\
\hline & 1 & 38 & & & & 2. & & & & & 2. & & & & & & & & & 40 & 74 & & 327 & 89 & 21 & 14 & & 1305.9 \\
\hline & d & 39 & & & & & 7. & & & & & & & & & & & & & 43 & 73 & & & 86 & 103 & 14 & $2.93^{\mathrm{a}}$ & 1305.9 \\
\hline & 1 & $4 c$ & & & & 5. & 9. & & & & 2. & & & & 0. & & & 15 & 1. & 77 & 123 & 01 & 255 & 91 & 8 & 15 & & 1313.2 \\
\hline $134-1,147-150$ & d & 41 & & 0.93 & 14.30 & 2.63 & 7.44 & 0.21 & & 12.50 & 1.92 & & & 1.80 & 0.19 & 0.00 & & 10.90 & 0.29 & 79 & 79 & 0.07 & 171 & 79 & 106 & 16 & $2.93^{\mathrm{a}}$ & 1313.2 \\
\hline $141-1,67-71$ & 1 & 42 & 40.10 & 1.07 & 16.00 & 5.09 & 14.30 & 0.16 & 9.93 & 3.42 & 2.78 & 0.02 & 0.08 & 7.43 & 0.11 & 0.00 & 100.49 & 21.00 & 1.08 & & & 0.06 & & & & & 2.59 & 1346.2 \\
\hline
\end{tabular}

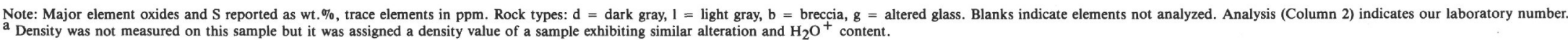


Table 2. Major and trace element data for reference samples and Leg 83 interlaboratory comparison sampies.

\begin{tabular}{|c|c|c|c|c|c|c|c|c|c|}
\hline \multirow{2}{*}{$\begin{array}{l}\text { Major } \\
\text { elements } \\
\text { (wt. \%) }\end{array}$} & \multicolumn{3}{|c|}{ BIR-1 } & \multicolumn{3}{|c|}{ BM } & \multicolumn{3}{|c|}{ Interlab. comparison samples } \\
\hline & $\begin{array}{l}\text { This } \\
\text { study }\end{array}$ & $2 \mathrm{~s}$ & $\begin{array}{c}\text { Gladney } \\
(1983)\end{array}$ & $\begin{array}{l}\text { This } \\
\text { study }\end{array}$ & $2 \mathrm{~s}$ & $\begin{array}{l}\text { Abbey } \\
(1980)\end{array}$ & $\begin{array}{c}77-1, \\
44-53 \mathrm{~cm}\end{array}$ & $\begin{array}{c}97-2, \\
74-89 \mathrm{~cm}\end{array}$ & $\begin{array}{c}130-2 \\
44-58 \mathrm{~cm}\end{array}$ \\
\hline $\mathrm{SiO}_{2}$ & 47.89 & 0.30 & $47.94 \pm 1.39$ & 49.69 & 0.34 & 49.60 & 48.96 & 50.12 & 49.14 \\
\hline $\mathrm{TiO}_{2}$ & 0.95 & 0.012 & $0.93 \pm 0.05$ & 1.11 & 0.02 & 1.14 & 0.92 & 0.955 & 0.7 .5 \\
\hline $\mathrm{Al}_{2} \mathrm{O}_{3}$ & 15.76 & 0.10 & $14.76 \pm 0.79$ & 16.22 & 0.10 & 16.20 & 16.35 & 14.73 & 16.39 \\
\hline $\mathrm{Fe}_{2} \mathrm{O}_{3} \mathrm{~T}$ & 11.51 & 0.10 & $11.06 \pm 0.56$ & 9.66 & 0.10 & 9.68 & 9.84 & 10.56 & 9.01 \\
\hline $\mathrm{MnO}$ & 0.18 & 0.004 & $0.17 \pm 0.03$ & 0.146 & 0.004 & 0.145 & 0.179 & 0.177 & 0.151 \\
\hline $\mathrm{MgO}$ & 9.68 & 0.10 & $9.70 \pm 0.99$ & 7.49 & 0.08 & 7.46 & 8.27 & 8.39 & 9.12 \\
\hline $\mathrm{CaO}$ & 13.32 & 0.10 & $13.02 \pm 0.48$ & 6.37 & 0.08 & 6.46 & 12.41 & 12.73 & 13.19 \\
\hline $\mathrm{Na}_{2} \mathrm{O}$ & 1.84 & 0.06 & $1.62 \pm 0.09$ & 4.87 & 0.10 & 4.64 & 2.45 & 2.00 & 1.73 \\
\hline $\mathrm{K}_{2} \mathrm{O}(\mathrm{XRF})$ & 0.033 & 0.022 & & 0.183 & 0.004 & & 0.032 & 0.017 & 0.015 \\
\hline $\mathrm{K}_{2} \mathrm{O}$ (AAS) & 0.037 & 0.002 & $0.017-0.040$ & 0.183 & 0.004 & 0.203 & 0.024 & 0.009 & 0.008 \\
\hline $\mathrm{P}_{2} \mathrm{O}_{5}$ & 0.026 & 0.005 & $0.030-0.100$ & 0.12 & 0.006 & 0.105 & 0.06 & 0.07 & 0.05 \\
\hline \multirow{2}{*}{$\begin{array}{c}\text { Trace } \\
\text { elements } \\
(\mathrm{ppm})\end{array}$} & \multicolumn{3}{|c|}{ BE-N } & \multicolumn{3}{|c|}{ BHVO-1 } & \multicolumn{3}{|c|}{ Interlab comparison samples } \\
\hline & $\begin{array}{l}\text { This } \\
\text { study }\end{array}$ & $2 s$ & $\begin{array}{l}\text { Govindaraju } \\
\quad(1980)\end{array}$ & $\begin{array}{l}\text { This } \\
\text { study }\end{array}$ & $2 \mathrm{~s}$ & $\begin{array}{l}\text { Abbey } \\
(1982)\end{array}$ & $\begin{array}{c}77-1 \\
44-53 \mathrm{~cm}\end{array}$ & $\begin{array}{c}97-2 \\
74-89 \mathrm{~cm}\end{array}$ & $\begin{array}{c}130-2 \\
44-58 \mathrm{~cm}\end{array}$ \\
\hline F & - & - & - & - & - & - & 83 & 66 & 63 \\
\hline $\mathrm{Cr}$ & 373 & 7.4 & 360 & - & - & - & 301 & 259 & 373 \\
\hline $\mathrm{Co}$ & 64 & 6.4 & 61 & - & - & - & 43 & 42 & 40 \\
\hline $\mathrm{Ni}$ & 264 & 3.6 & 267 & - & - & - & 126 & 88 & 145 \\
\hline $\mathrm{Cu}$ & 82 & 3.6 & 72 & - & - & - & 89 & 93 & 84 \\
\hline $\mathrm{Zn}$ & 123 & 2.2 & 120 & - & - & - & 65 & 67 & 58 \\
\hline $\mathrm{Ga}$ & 17 & 1.6 & 17 & - & - & - & 15 & 16 & 15 \\
\hline $\mathrm{Rb}$ & - & - & - & 9 & 0.8 & 10 & $<5$ & $<5$ & $<5$ \\
\hline $\mathrm{Sr}$ & - & - & - & 399 & 1.6 & 400 & 77 & 67 & 66 \\
\hline $\mathrm{Y}$ & - & - & - & 27 & 1.2 & 27 & 25 & 27 & 21 \\
\hline $\mathrm{Zr}$ & - & - & - & 176 & 1.6 & 180 & 61 & 63 & 51 \\
\hline $\mathrm{Nb}$ & - & - & - & 18 & 0.8 & 19 & $<5$ & $<5$ & $<5$ \\
\hline
\end{tabular}

Note: Analytical errors are given as \pm 2 standard deviations (2s; i.e., on a $95 \%$ confidence level). Dashes indicate elements not analyzed.

Table 3. Mean and standard deviation of least-altered basalt and unaltered glass analyses from Hole 504B.

\begin{tabular}{lcccc}
\hline \multicolumn{3}{c}{ Basalt $^{\mathrm{a}}$} & \multicolumn{2}{c}{ Glass $^{\mathrm{b}}$} \\
\hline & Mean & $1 \sigma$ & Mean & $1 \sigma$ \\
\hline $\mathrm{SiO}_{2}$ & 50.06 & 0.45 & 50.66 & 0.66 \\
$\mathrm{TiO}_{2}$ & 0.94 & 0.09 & 0.97 & 0.07 \\
$\mathrm{Al}_{2} \mathrm{O}_{3}$ & 15.43 & 0.59 & 14.96 & 0.64 \\
$\mathrm{Fe}_{2} \mathrm{O}_{3}$ & 2.98 & 0.59 & $1.65^{\mathrm{c}}$ & 0.07 \\
$\mathrm{FeO}$ & 6.65 & 0.67 & $8.42^{\mathrm{c}}$ & 0.36 \\
$\mathrm{MnO}$ & 0.17 & 0.02 & $0.17^{\mathrm{d}}$ & 0.02 \\
$\mathrm{MgO}$ & 8.44 & 0.38 & 8.20 & 0.34 \\
$\mathrm{CaO}$ & 12.94 & 0.43 & 12.78 & 0.24 \\
$\mathrm{Na}_{2} \mathrm{O}$ & 2.19 & 0.30 & 2.00 & 0.15 \\
$\mathrm{~K}_{2} \mathrm{O}$ & 0.02 & 0.01 & 0.03 & 0.01 \\
$\mathrm{P}_{2} \mathrm{O}_{5}$ & 0.07 & 0.01 & 0.08 & 0.01 \\
$\mathrm{CO}_{2}$ & 0.10 & .03 & $0.10^{\mathrm{d}}$ & 0.30 \\
$\mathrm{Total}$ & 99.99 & & 100.02 & \\
$\mathrm{Fe}_{2} \mathrm{O}_{3}{ }^{\mathrm{T}}$ & 10.37 & 0.66 & 11.00 & 0.47 \\
\hline
\end{tabular}

a Mean and standard deviation of 58 "leastaltered" basalt analyses from the Leg 70 section of Hole 504B (Hubberten et al., 1983). Least-altered analyses were selected based on $\mathrm{K}_{2} \mathrm{O}$ contents less than 0.10 wt. $\%$ and recalculated water-free. Average does not include "anomalous" high P and Ti units (see text).

$\mathrm{b}$ Mean and standard deviation of 51 unaltered glass analyses from Hole 504B, excluding "anomalous" high $\mathrm{P}$ and Ti units (see text; Natland et al., 1983).

c Assuming $\mathrm{Fe}^{3+} / \mathrm{Fe}^{\mathrm{T}}=0.15$.

$\mathrm{d}$ Assigned value of average least-altered basalt from (a). composition, Leg 83 basalts exhibit trends toward losses of $\mathrm{SiO}_{2}, \mathrm{CaO}, \mathrm{TiO}_{2}$; decreases in density (relative to the average least-altered Leg 83 basalt); gains of $\mathrm{MnO}$, $\mathrm{Na}_{2} \mathrm{O}, \mathrm{CO}_{2}, \mathrm{H}_{2} \mathrm{O}^{+}$, S; slight gains of $\mathrm{MgO}$; increased oxidation of $\mathrm{Fe}$; and variable changes in $\mathrm{Al}_{2} \mathrm{O}_{3}$.

\section{Rare Earth Elements}

Minor differences occur in the rare earth element (REE) patterns of altered samples compared to less-altered samples. The $\mathrm{La} / \mathrm{Sm}$ enrichment factor generally increases slightly at high $\mathrm{H}_{2} \mathrm{O}^{+}$contents, and the small negative Eu anomaly that is sometimes present disappears with increasing $\mathrm{H}_{2} \mathrm{O}^{+}$(Fig. 2A). Similar Eu enrichments of hydrothermally altered submarine basalts have been interpreted to be due to reducing conditions and the presence of secondary albite (Humphris et al., 1978).

The altered glass of Sample 504B-81-1, 83-86 cm, compared to the adjacent crystalline basalt, illustrates the light REE enrichments of the more altered samples (Fig. 2B). Similar light REE enrichment and mobility have been observed in seafloor basalts affected by submarine "weathering" (Ludden and Thompson, 1979) and in "zeolite facies" metabasalts from Iceland and in ophiolites (Humphris et al., 1978; Menzies et al., 1977). In the case of the submarine metabasalt, it was suggested that secondary chlorite may be the source of the La enrichment (Humphris et al., 1978). 

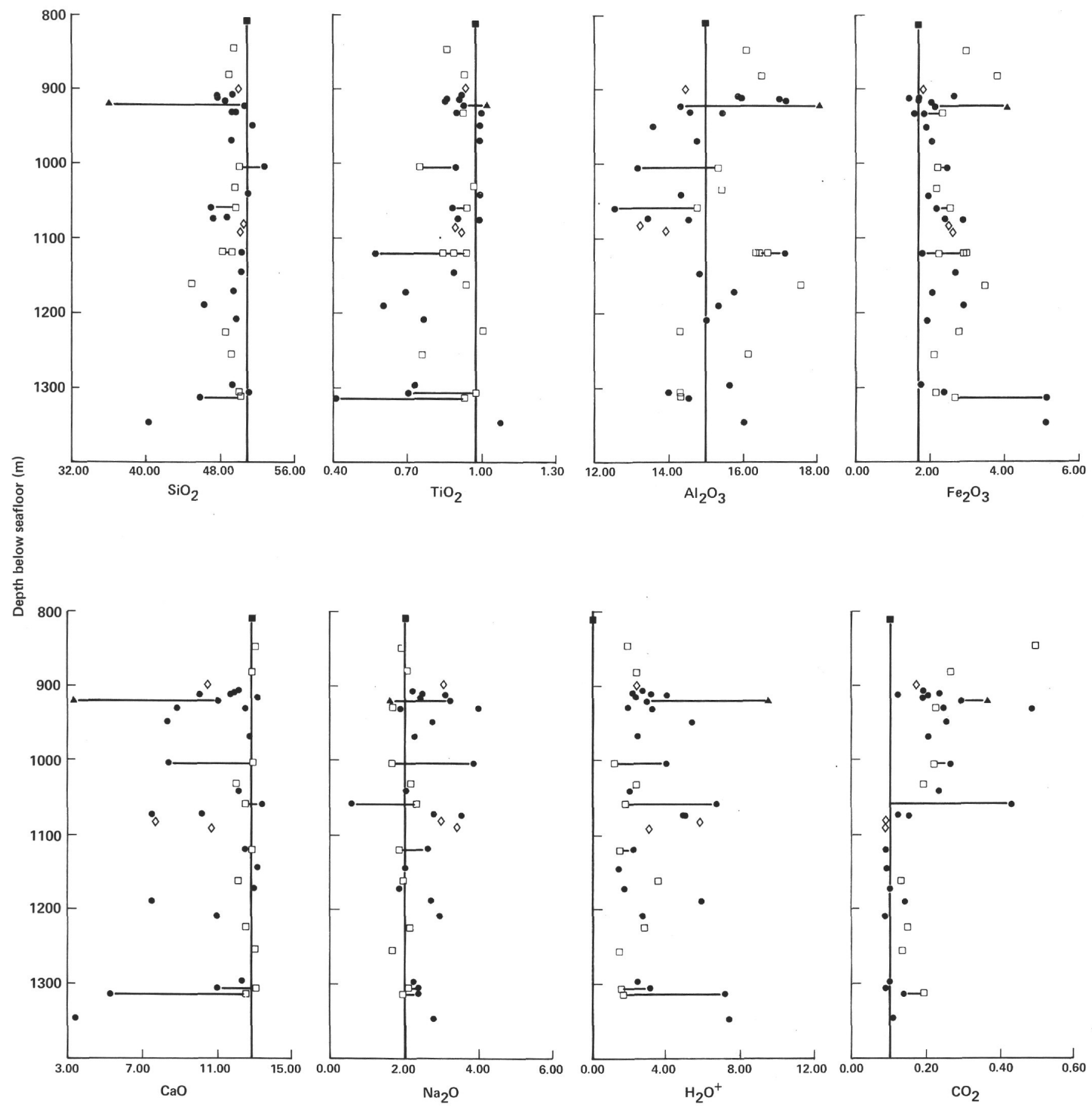

Figure 1. Bulk rock chemical analyses of altered basalts versus depth. Oxide data from Table 1 are plotted as wt. \% . $+=$ dark gray rock, circles $=$ light gray or green wall-rock alteration zone, triangle $=$ altered glassy pillow rim, $\mathrm{x}=$ breccia. Horizontal lines connect adjacent alteration zones from the same hand specimen. Average unaltered glass composition from the pillow section of Hole 504B (Table 3; Natland et al., 1983) is also plotted for comparison (square, and vertical line).

In contrast, either the light gray wall rock alteration zone of Sample 504B-104-2, 57-61 cm has been slightly depleted in total REE compared to the adjacent dark gray host rock or the latter has been enriched (Fig. 2B). This contrast remains a problem since there is apparently no significant difference in alteration mineralogy between these samples and others from Leg 83 .

\section{CORRELATION OF CHEMICAL AND MINERALOGICAL CHANGES}

The basalts recovered during Leg 83 frequently exhibit multistage alteration histories: Formation of greenschist-facies mineral parageneses was followed by zeolite-facies mineralogies. The chemistry of the bulk rocks 

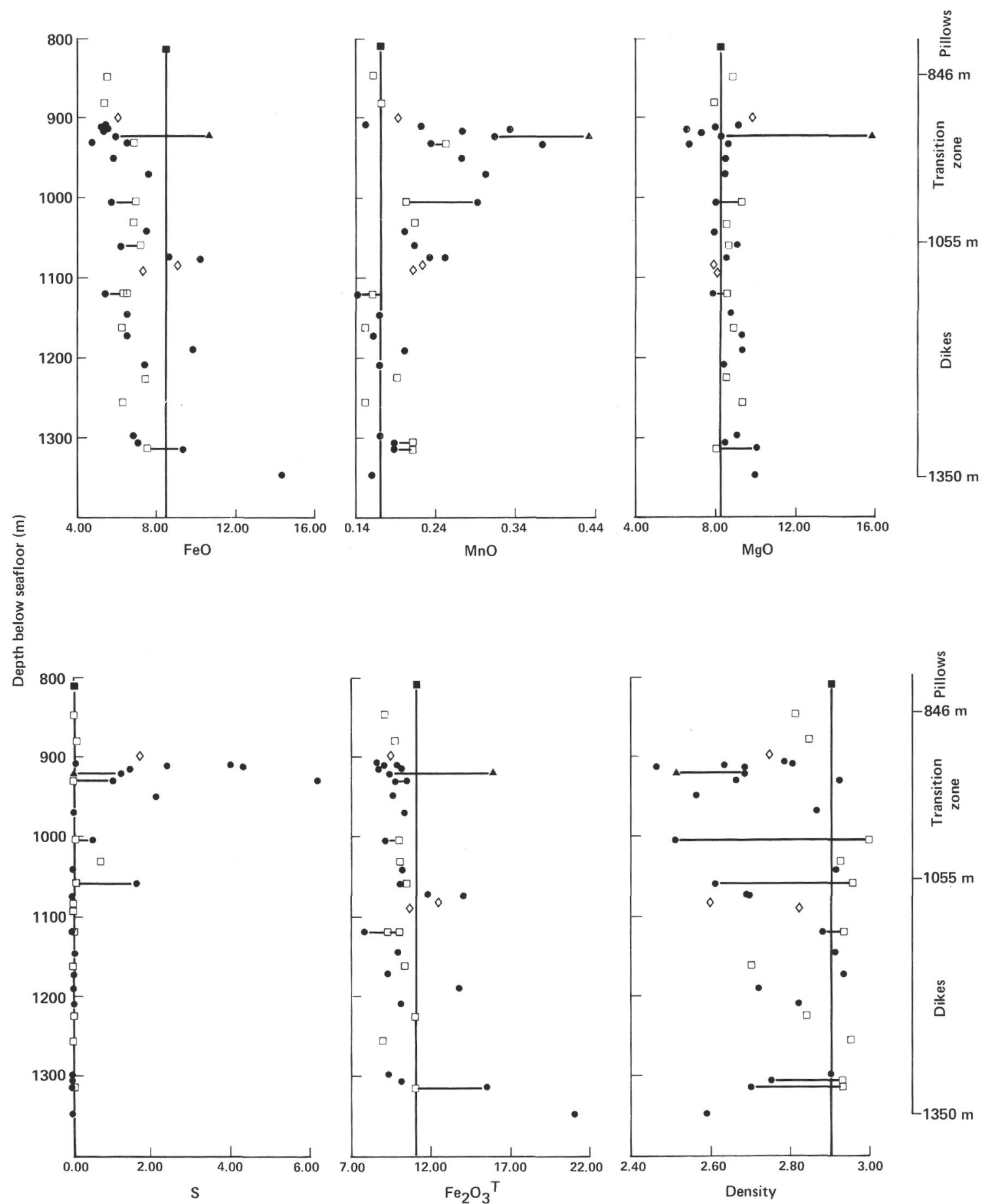

Figure 1. (Continued).

often reflects this complex alteration history. Individual plots of wt. $\%$ oxide versus $\mathrm{H}_{2} \mathrm{O}^{+}$content frequently exhibit various different trends (Fig. 3), reflecting alteration at differing water/rock ratios, primary substrate control of secondary mineralogy, and superimposed alteration effects. Specific examples are discussed, followed by discussion of the general chemical trends in the hole.

\section{Albitization}

Sample 504B-91-1, 66-70 cm is a fine-grained pillow fragment consisting of a dark gray host rock (Table 1,
Analysis 17) and a 1.5-cm-wide light gray alteration zone (Table 1, Analysis 16) adjacent to a quartz vein with a 3$\mathrm{mm}$ silicified wall-rock zone. In the light gray zone albite totally replaces plagioclase phenocrysts and extensively replaces microlites, olivine is replaced by chloritesmectite, titanomagnetite is totally replaced by sphene, clinopyroxene phenocrysts are unaltered, groundmass pyroxene is slightly cloudy, and disseminated secondary pyrite is common. In the adjacent dark gray zone plagioclase, clinopyroxene, and titanomagnetite are essentially unaltered, and olivine is replaced by a mixture of chlorite-smectite and talc. 


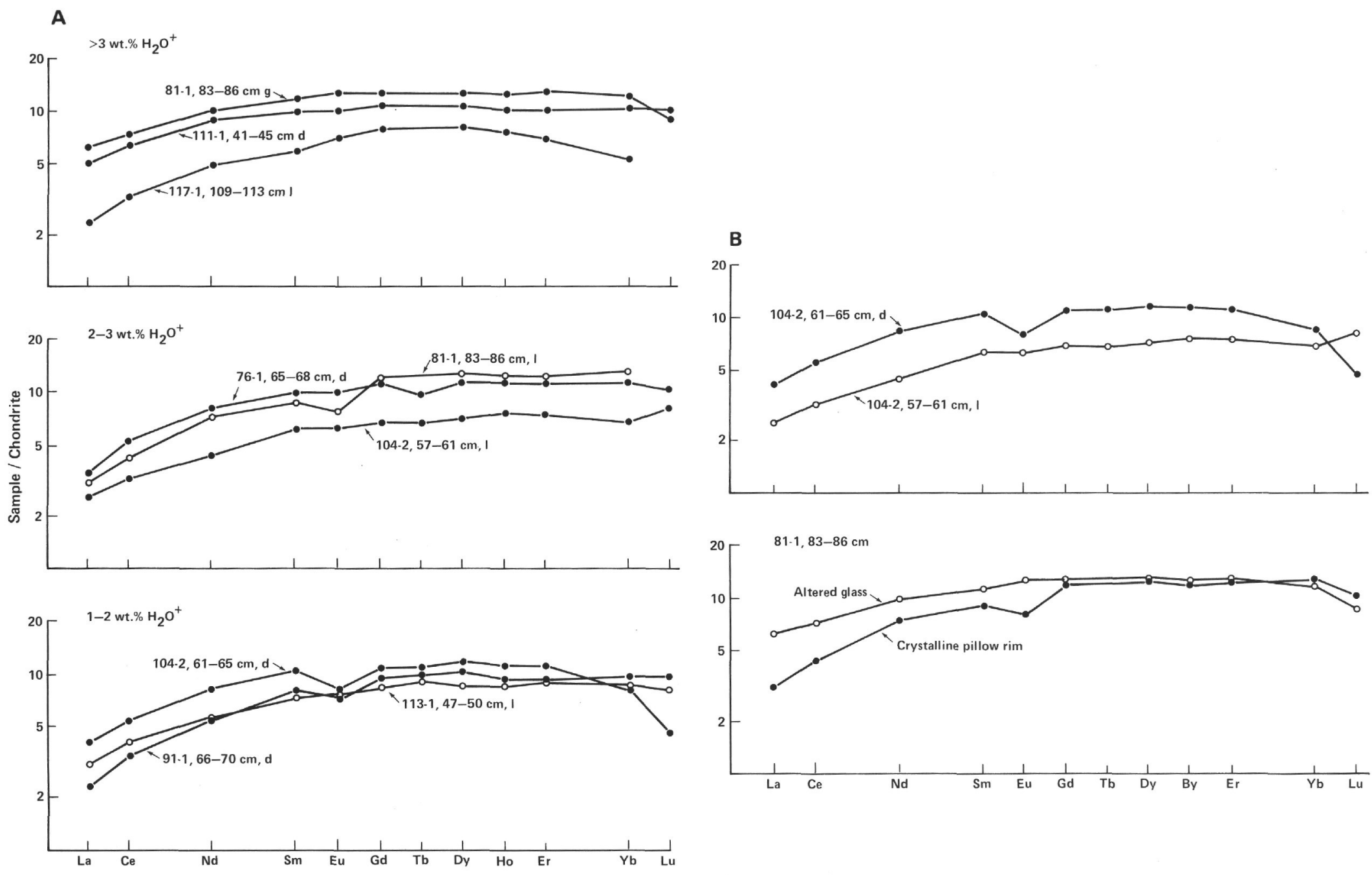

Figure 2. Chondrite-normalized rare earth element (REE) patterns for Leg 83; Hole 504B basalts. A. Variations in REE patterns with wt. $\% \mathrm{H}_{2} \mathrm{O}^{+}$. B. Altered zones and adjacent less-altered basalts. $\mathrm{l}=$ light gray wall-rock alteration zone, $\mathrm{d}=$ dark gray basalt, $\mathrm{g}=$ altered glassy pillow rim. 
J. C. ALT, R. EMMERMANN
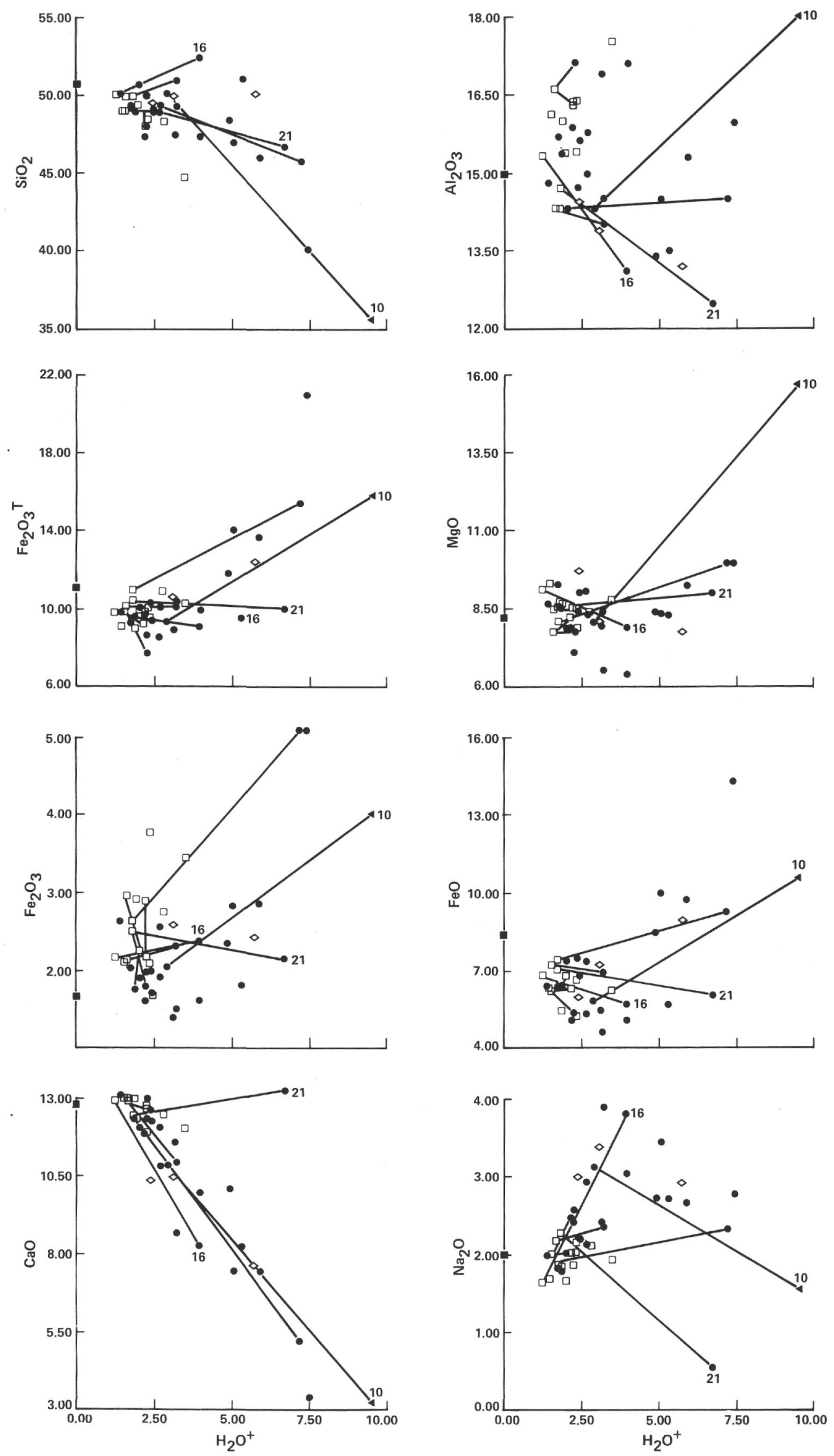

Figure 3. Bulk-rock chemical analyses of altered basalts plotted as oxide wt. $\%$ versus wt. $\% \mathrm{H}_{2} \mathrm{O}^{+}$. Symbols as in Figure 1. Individual samples discussed in text are labeled with analysis numbers from Table 1. 
It can be seen from Figure 3 that the light gray zone is enriched in $\mathrm{Si}$ and $\mathrm{Na}$ and depleted in $\mathrm{Al}$ and $\mathrm{Ca}$ relative to the dark gray host rock, reflecting the replacement of plagioclase by albite in the light gray zone. The large range in $\mathrm{Al}_{2} \mathrm{O}_{3}$ values at $\mathrm{H}_{2} \mathrm{O}$ contents below 2.5 wt. $\%$ in Figure 2 falls mostly within the range of least-altered basalts from the pillow section of the hole (Hubberten et al., 1983) and probably reflects primary compositional variation to a large degree. Recalculation of $\mathrm{Al}_{2} \mathrm{O}_{3}$ contents as moles per cubic centimeter decreases the variability and, by eliminating the effects of density variations caused by alteration, supports this suggestion. The trends between adjacent samples connected by lines in Figure 3 are not primary, however: normalization does not remove these differences. The dark gray zone is slightly enriched in $\mathrm{Mg}$ and $\mathrm{Fe}$ relative to the light gray zone, probably because talc and pyrite are present in the dark gray zone.

\section{Chloritization}

Sample 504B-81-1, 83-86 cm consists of a light gray fine-grained pillow rim (Table 1, Analysis 9) and adjacent former glassy pillow crust (Table 1, Analysis 10). The glass is totally replaced by chlorite, and plagioclase phenocrysts in both samples are extensively replaced by albite and minor amounts of Ca-zeolites. In the crystalline rock clinopyroxene phenocrysts have reaction rims of actinolite, and titanomagnetite is replaced by sphene. The former glassy rim is highly enriched in $\mathrm{Al}, \mathrm{Fe}, \mathrm{Mg}$, and $\mathrm{H}_{2} \mathrm{O}$ and depleted in $\mathrm{Si}$ and $\mathrm{Ca}$ relative to the adjacent crystalline rock (Fig. 3), reflecting the total breakdown of the glass and replacement by chlorite. The bulk glass composition reflects the presence of albite and relict clinopyroxene and plagioclase phenocrysts in addition to the chlorite. The higher Na content of the crystalline pillow rim reflects the albitization of plagioclase microphenocrysts and microlites, which are not present in the altered glassy portion.

Formation of secondary minerals in Leg 83 basalts is strongly controlled by precursor mineralogy, with glass being replaced by clay minerals (Alt et al., this volume). Glass also reacts more readily than crystalline basalt (Seyfried and Bischoff, 1979, 1981). These observations suggest that a crystalline basalt undergoing alteration under the same conditions as the glassy pillow rim would not exhibit the same alteration products or bulk composition. A similar substrate control of secondary mineralogy was described in submarine basalts from the Carlsberg Ridge where glassy pillow rims were replaced by chlorite, and crystalline pillow interiors were replaced by actinolite, chlorite, albite, and sphene (termed hyalospilite and orthospilite, respectively; Cann, 1969). This variation was interpreted to result from differing nucleation effects of the various substrates (Cann, 1969). From experimental data, this same sort of variation was interpreted to result from varying water/rock ratios by Seyfried et al. (1978); the glassy pillow rim was interpreted to have been altered at a higher water/rock ratio than the crystalline pillow interior. However, the latter interpretation does not take into account the kinetic effects: glass alters more readily than crystalline basalt at these temperatures $\left(70-300^{\circ} \mathrm{C}\right.$; Seyfried and Bischoff, 1979, 1981). Thus, although a high water/rock ratio is required to account for the large $\mathrm{MgO}$ increase in the altered glass, the complete alteration of the glass to chlorite probably reflects the effects of both water/rock ratio and substrate control of secondary mineralogy.

In the case of identical substrates (i.e., crystalline basalt), variations in the water/rock ratio should lead to differences in mineral assemblages and bulk chemistry. Both theoretical and experimental evidence indicate that chlorite and quartz should be more abundant at higher water/rock ratios, whereas albite should be more common at lower ratios (Mottl, 1983; Reed, 1983). Such effects ae often present adjacent to veins in Leg 83 basalts where narrow (hundreds of microns) wall-rock zones are totally recrystallized to chlorite and quartz, whereas farther from the vein the rock is less extensively altered and contains albite and chlorite, lacking quartz. Similar effects can be observed on a slightly larger scale, where the centimeter-sized light gray alteration zones around clay mineral veins are more extensively recrystallized than adjacent dark gray host rocks. Variations in the water/rock ratio probably caused these differences in extent of recrystallization, as well as in mineral assemblages, contributing to the scatter of trends in Figure 3.

\section{Zeolitization}

Sample 504B-97-1, 88-90 cm (Table 1, Analysis 21) consists of a light gray friable dike rock and is characterized by total replacement of plagioclase by laumontite. Olivine is replaced by chlorite with minor expandable layers, titanomagnetite is replaced by sphene, clinopyroxene is slightly cloudy, and disseminated secondary pyrite is common. The adjacent dark gray host rock (Table 1, Analysis 20) is much less extensively altered. Plagioclase is only partly replaced by albite, chlorite, and minor prehnite and laumontite. Olivine is replaced by chlorite with minor expandable layers, titanomagnetite is partly replaced by sphene, clinopyroxene is slightly cloudy, and secondary pyrite is much less abundant than in the adjacent light gray zone.

The zeolite-rich light gray zone is enriched in $\mathrm{Ca}$ and $\mathrm{H}_{2} \mathrm{O}$ and depleted in $\mathrm{Si}, \mathrm{Al}$, and $\mathrm{Na}$ relative to the adjacent dark gray host rock (Fig. 3), reflecting the total replacement of plagioclase by laumontite in the light gray rock. The slight variation in $\mathrm{Fe}$ and $\mathrm{Mg}$ contents may reflect differences in clay mineral abundances between the two zones.

The chemical changes associated with zeolite formation in Leg 83 basalts are different from those of dredged "zeolite facies" metabasalts from the seafloor, which exhibit increased $\mathrm{Na}_{2} \mathrm{O}$ and $\mathrm{H}_{2} \mathrm{O}$ contents (Miyashiro et al., 1971; Shido et al., 1974). The Na-enriched basalts contain zeolite assemblages characterized by Na-zeolites (mostly analcite; Miyashiro et al., 1971), which are restricted to the lower zeolite facies (Coombs, 1971) and have been observed in drilled submarine basalts altered at relatively low temperatures (i.e., less than $100^{\circ} \mathrm{C}$; Alt, 1982). Thus, the $\mathrm{Ca}$ and $\mathrm{H}_{2} \mathrm{O}^{+}$enrichments and $\mathrm{Si}, \mathrm{Al}$, and $\mathrm{Na}$ depletions characteristic of Ca-zeolite formation in Leg 83 basalts probably represent higher-temperature 
effects than the Na-enrichments observed in other seafloor basalts interpreted to have been metamorphosed under "zeolite-facies" conditions.

The formation of zeolites postdates that of greenschist-facies mineralogies in Leg 83 basalts, and both parageneses occur in the same samples. This suggests that many altered basalts from Leg 83 must have undergone, first, albitization of plagioclase and loss of $\mathrm{Ca}$ and gain of $\mathrm{Na}$, followed by zeolitization of the remaining plagioclase with concomitant gain of $\mathrm{Ca}$ and loss of $\mathrm{Na}$. The resultant bulk rocks thus may often reflect the combined effects of both alteration stages.

\section{Variation in Composition with Depth}

Variation in composition of basalts with depth (Fig. 1) can be correlated with mineralogical changes. Bulkrock $\mathrm{H}_{2} \mathrm{O}^{+}$contents increase from an average of about $1 \mathrm{wt} . \%$ in the overlying pillow section (Emmermann, this volume) to greater than 2 wt. $\%$ below $836 \mathrm{~m}$, where clay minerals become more chloritic and sphene appears. Greenschist-facies mineral parageneses first appear at $898 \mathrm{~m}$ and are present to the bottom of the hole (Alt et al., this volume). Below about $900 \mathrm{~m}$ the breakdown of plagioclase results in the lower $\mathrm{CaO}$ contents and some of the variability in $\mathrm{Al}_{2} \mathrm{O}_{3}$. The greater $\mathrm{H}_{2} \mathrm{O}$ contents below about $900 \mathrm{~m}$ reflect the greater extent of alteration of basalts containing greenschistfacies parageneses. The decrease in dry bulk density of all altered samples relative to the average least-altered basalt $\left(2.9 \mathrm{~g} / \mathrm{cm}^{3}\right.$; Fig. 1 ; Hole 504B summary chapter) indicates a net loss of material from the bulk rocks during alteration.

$\mathrm{MnO}$ and $\mathrm{S}$ are enriched in the transition zone below about $900 \mathrm{~m}$ and reach a maximum around $910-930 \mathrm{~m}$ (Fig. 1). Bulk $\mathrm{CO}_{2}$ contents exhibit similar enrichment, although no clear maximum occurs and high $\mathrm{CO}_{2}$ contents also occur at shallower depths. Bulk-rock sulfur distribution reflects the abundance of secondary sulfides, mainly pyrite, which is more common in the transition zone than in the underlying dikes and reaches maximum abundance in the sulfide-rich stockwork zone at $910-928 \mathrm{~m}$ (Alt et al., this volume; Honnorez et al., this volume).

The high MnO contents of the transition zone rocks are due in part to the presence of Mn-rich clay minerals in the rocks. Clay mineral $\mathrm{MnO}$ contents versus depth follow the bulk rock $\mathrm{MnO}$ contents exactly (Fig. 1; Alt et al., this volume). Calcites enriched in Mn have been identified from 910 to $946 \mathrm{~m}$, and there is a general trend toward increasing $\mathrm{MnO}$ with $\mathrm{CO}_{2}$ in bulk rocks (Fig. 4A), indicating that Mn-rich calcite may also contribute to the higher bulk-rock $\mathrm{MnO}$ contents in the transition zone.

Bulk-rock $\mathrm{CO}_{2}$ contents refiect the distribution of calcite in the hole: calcite is abundant in the stockwork zone $(910-928 \mathrm{~m})$, relatively common in the transition zone, but extremely rare in the dike section (Alt et al., this volume).

The bulk rock $\mathrm{Mn}$ and $\mathrm{S}$ enrichments in the transition zone and the presence of $\mathrm{Fe}, \mathrm{Cu}, \mathrm{Zn}$, and $\mathrm{Pb}$ sulfides in stockwork-like veins near the top of the transition zone (Honnorez et al., this volume) suggest that the transition zone section penetrated by Hole 504B was once within or near a hydrothermal upflow zone. Such metal enrichments and sulfide deposits would be expected to occur where hot metal- and sulfur-rich hydrothermal fluids passed through the crust. The Mn and S enrichments in the transition zone basalts indicate that these rocks were not the source rocks for the mineralizing fluids depositing the sulfides in the stockwork-like zone. $\mathrm{Cu}$ and $\mathrm{Zn}$ contents of the basalts from the underlying dike section are similar to unaltered basalts (Table 1; Cann, 1981), indicating that these rocks were also probably not the source of the mineralizing fluids. Variations in the $\mathrm{Cu}$ and $\mathrm{Zn}$ contents of the dike rocks suggest that some mobilization of these elements did occur, however.

Several samples are enriched in total iron relative to the fresh glass composition, whereas most samples exhibit lower total iron concentrations (Fig. 4B). The samples enriched in total iron are also clay-rich, and all except one (Table 1, Analysis 33) are from intervals in the
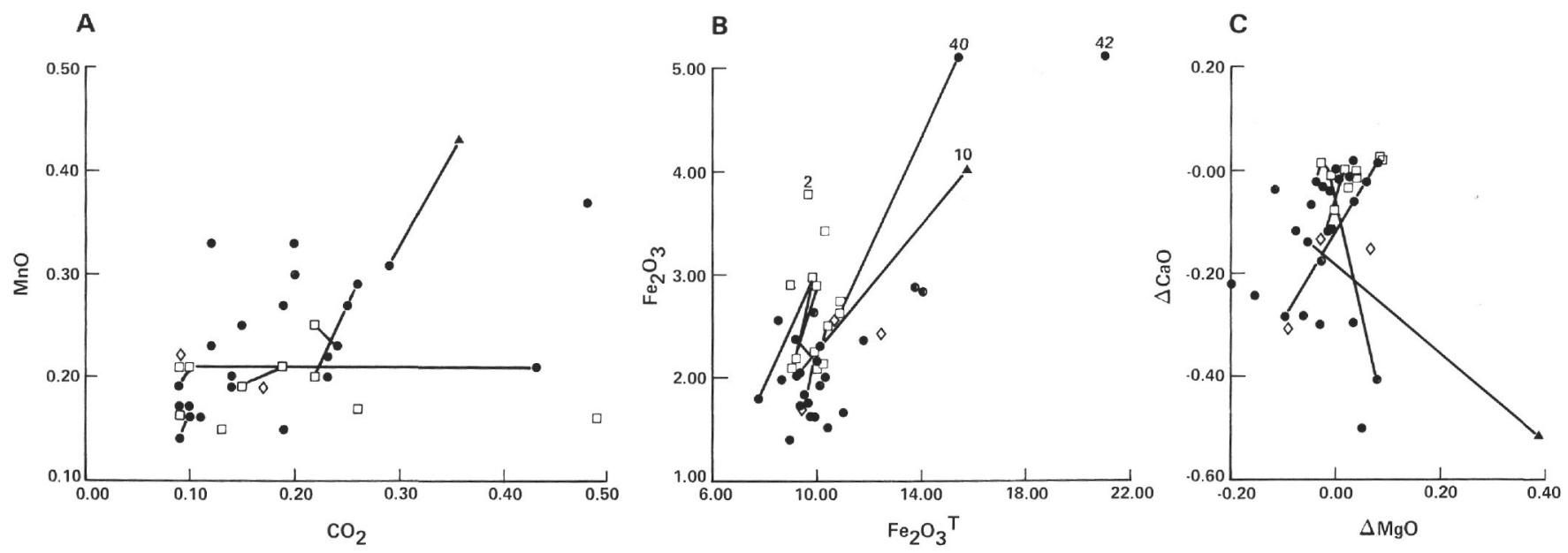

Figure 4. Bulk rock analyses of altered basalts. Symbols as in Figure 1. A and B plotted as oxide wt. \%, C plotted as fluxes in moles oxide $/ 100 \mathrm{~cm}^{3}$ basalt (from Table 4, see text). 
hole where clay minerals are enriched in iron (965-1070 $\mathrm{m}$ and $1300 \mathrm{~m}$; Alt et al., this volume), suggesting that the presence of Fe-rich clay minerals are responsible for the observed iron enrichments. No correlation exists between total iron and sulfur contents, indicating that the presence of pyrite is not responsible for iron enrichment of the rocks. However, sulfur-rich rocks do tend to have lower ferric iron contents than sulfur-poor rocks. The range of total iron content of the remainder of the samples falls within that of "least altered" pillow basalts from the hole (Hubberten et al., 1983).

The general trend toward higher $\mathrm{Fe}_{2} \mathrm{O}_{3}$ content with higher total iron (Fig 4B), especially in clay-rich samples, suggests that ferric iron in clay minerals is responsible. However, Sample 504B-76-1, 65-68 cm (Table 1, Analysis 2) contains secondary hematite overgrowths on primary titanomagnetite that may account for the high $\mathrm{Fe}_{2} \mathrm{O}_{3}$ content of this sample.

Several samples of light gray and green alteration halos from below $1118 \mathrm{~m}$ have lost large amounts of $\mathrm{TiO}_{2}$ relative to adjacent host rocks (Table 1, Analyses 26, 32, 33, 37, 38 and 40; Fig. 1). Titanomagnetite is only slightly altered to sphene in the dark gray host rock, but is almost totally replaced by sphene in the light gray zones. Thus breakdown of titanomagnetite has led to loss of $\mathrm{Ti}$, but it is uncertain where the $\mathrm{Ti}$ was deposited, perhaps as sphene in nearby veins or in the adjacent host rock.

The sample from the bottom of the drilled dike section (Table 1, Analysis 42) is enriched in total iron and $\mathrm{H}_{2} \mathrm{O}^{+}$, and depleted in $\mathrm{Si}$ and $\mathrm{Ca}$ relative to most of the dike samples (Fig. 1 and 3). This sample is from a zone at the bottom of the dike section $(1340-1350 \mathrm{~m})$ where the basalts are highly fractured and extensively recrystallized, in contrast to the generally small extent of fracturing and recrystallization observed in the central part of the dike section. The lowermost $10 \mathrm{~m}$ of the dike section may have been a zone of higher primary permeability allowing circulation of greater amounts of fluid and facilitating more extensive reaction of the basalts.

\section{WATER/ROCK RATIOS AND CHEMICAL FLUXES}

Chemical fluxes were calculated as g oxide $/ 100 \mathrm{~cm}^{3}$ basalt relative to the average unaltered glass composition from the pillow section of the hole and assuming constant volume alteration. This assumption appears justified since the basalts are generally only partly recrystallized and have recognizable igneous texture. Dry bulk densities calculated from shipboard wet-bulk density and porosity measurements made on least-altered Leg 83 samples average $2.9 \mathrm{~g} / \mathrm{cm}^{3}$, with a standard deviation of $3 \%$ and a maximum range of 5\% (Hole 504B summary chapter). This average value is identical to that for the pillow section of the core (excluding two lowdensity breccia samples; Karato, 1983). The value of $2.9 \mathrm{~g} / \mathrm{cm}^{3}$ was chosen for the average unaltered basalt density, and altered rock densities were taken from Table 1 for the flux calculations. Calculated gains and losses are given along with errors in Table 4.

\section{Comparison with Dredged Rocks}

Humphris and Thompson (1978) normalized bulkrock data to constant $\mathrm{A} 1$ to calculate chemical changes. Since $\mathrm{Al}$ was mobile during the alteration of Leg 83 basalts, normalization to $\mathrm{Al}$ was not reasonable for the data in Table 1. To make a more direct comparison, the data from Humphris and Thompson (1978) were recalculated in the same way as the Leg 83 data in Table 4. The recalculated fluxes are generally similar to those based on $\mathrm{Al}$ normalization, but exhibit greater Si losses. With the exception of the altered glass sample (Tables 1 and 4, Analysis 10) $\mathrm{MgO}$ gains for Leg 83 basalts are generally much less than those reported for the dredged basalts (Fig. 5). The MgO fluxes for Leg 83 basalts center around zero, with about one third of the values being negative. More than half of the analyses have $\mathrm{MgO}$ gains within $\pm 2 \mathrm{~g} / 100 \mathrm{~cm}^{3}$ of zero, which can be attributed to primary compositional variability if one assumes that the range in composition of the least-altered basalts from the pillow section of the hole (Hubberten et al., 1983; Honnorez et al., 1983) reflects primary compositional variation. Losses of $\mathrm{CaO}$ are generally smaller and $\mathrm{Na}_{2} \mathrm{O}$ more consistently gained in Leg 83 basalts than in the dredged rocks, whereas $\mathrm{SiO}_{2}$ losses are generally similar in the two groups. The net negative changes in Table 4 are due to the decrease in density and net loss of material from altered samples.

Part of the differences in chemical changes between the dredged and drilled rocks may arise because of the multiple alteration effects observed in Leg 83 basalts. Superimposition of zeolitization of plagioclase on rocks in which plagioclase had been previously partly albitized could have resulted in addition of $\mathrm{Ca}$ and loss of $\mathrm{Na}$ from rocks that had previously lost $\mathrm{Ca}$ and gained $\mathrm{Na}$. Another difference results from the alteration of the Hole 504B transition zone basalts in a hydrothermal upflow zone: $\mathrm{Mn}$ and $\mathrm{S}$ are consistently enriched in these basalts, but not in the dredged rocks.

The dredged basalts that were studied by Humphris and Thompson (1978) also were extensively recrystallized (mostly greater than 90\%) and contain abundant chlorite, whereas the Leg 83 samples are only locally more than about $50 \%$ recrystallized (e.g., in narrow wall-rock alteration zones along veins and at the bottom of the dike section). Dredged samples of hydrothermally altered submarine basalts are obtained from tectonically exposed areas such as fracture zones and faults. Such fractures, if they existed at the time of alteration of the rocks, could have served as conduits for fluid circulation causing alteration at high water/rock ratios and resulting in the extensive recrystallization often observed in dredged samples.

Pillow basalts apparently composed all the samples studied by Humphris and Thompson (1978), whereas the Leg 83 samples consist of both pillows and dikes. Of the $462 \mathrm{~m}$ of basalts containing greenschist-facies parageneses penetrated by Hole 504B, only about $100 \mathrm{~m}$ consist of pillow basalts, and these are restricted to the transition zone. This suggests that if the Hole 504B sec- 
Table 4. Chemical fluxes in grams per $100 \mathrm{~cm}^{3}$ basalt, Hole 504B.

\begin{tabular}{|c|c|c|c|c|c|c|c|c|c|c|c|c|c|c|c|c|c|}
\hline $\begin{array}{l}\text { Core-Section } \\
\text { (interval in cm) }\end{array}$ & $\begin{array}{l}\text { Rock } \\
\text { type }\end{array}$ & Analysis & $\mathrm{SiO}_{2}$ & $\mathrm{TiO}_{2}$ & $\mathrm{Al}_{2} \mathrm{O}_{3}$ & $\mathrm{FeO}$ & $\mathrm{Fe}_{2} \mathrm{O}_{3}$ & $\mathrm{MnO}$ & $\mathrm{MgO}$ & $\mathrm{CaO}$ & $\mathrm{Na}_{2} \mathrm{O}$ & $\mathrm{K}_{2} \mathrm{O}$ & $\mathrm{P}_{2} \mathrm{O}_{5}$ & $\mathrm{H}_{2} \mathrm{O}^{+}$ & $\mathrm{CO}_{2}$ & $\mathrm{Fe}_{2} \mathrm{O}_{3}{ }^{\mathrm{T}}$ & $\mathrm{s}^{\mathrm{a}}$ \\
\hline $72-2,126-129$ & d & 1 & -9.22 & -0.42 & 1.58 & 3.39 & -9.08 & -0.04 & 0.32 & -0.53 & -0.49 & -0.03 & -0.06 & 5.28 & 1.09 & -6.67 & -0.06 \\
\hline $76-1,65-68$ & d & 2 & -9.17 & -0.20 & 3.19 & 5.95 & -9.42 & -0.01 & -1.41 & -0.99 & -0.01 & -0.03 & -0.06 & 6.70 & 0.45 & & 0.14 \\
\hline $78-1,102-106$ & b & 3 & -11.01 & -0.29 & $\begin{array}{l}-3.93 \\
-3.93\end{array}$ & -0.13 & -8.01 & 0.03 & 5.19 & -8.57 & 2.45 & -0.00 & -0.04 & 6.60 & 0.18 & -6.09 & 4.51 \\
\hline $79-2,62-66$ & 1 & 4 & -10.69 & -0.28 & 0.54 & 2.36 & -9.52 & -0.08 & 1.53 & -3.42 & 0.20 & -0.03 & -0.07 & 7.39 & 0.24 & -8.19 & 0.11 \\
\hline $79-3,147-149$ & 1 & 5 & -14.19 & -0.27 & 1.14 & -0.22 & -10.08 & 0.12 & -0.68 & -3.74 & 1.12 & -0.03 & -0.06 & 6.10 & 0.35 & -4.46 & 10.98 \\
\hline $80-1,33-37$ & i & 6 & -21.99 & -0.58 & 1.06 & -1.10 & -10.01 & 0.37 & -2.33 & -6.55 & 0.59 & -0.03 & -0.10 & 8.26 & 0.03 & -8.34 & 6.06 \\
\hline $80-2,63-67$ & 1 & 7 & -30.31 & -0.60 & -1.32 & -0.78 & -11.82 & 0.32 & -6.28 & -12.46 & 1.70 & -0.04 & -0.08 & 9.77 & 0.20 & -7.35 & 10.37 \\
\hline $80-3,124-133$ & i & 8 & -18.01 & -0.56 & 2.44 & 0.55 & -10.46 & 0.23 & -4.12 & -2.22 & 0.69 & -0.03 & -0.10 & 6.06 & 0.22 & -8.64 & 3.71 \\
\hline $81-1,83-86$ & 1 & 9 & -12.38 & -0.35 & -5.06 & 0.74 & -8.66 & 0.34 & 0.49 & -7.85 & 2.62 & -0.01 & -0.10 & 7.77 & 0.49 & -6.87 & 3.12 \\
\hline $81-1,83-86$ & g. & 10 & -57.31 & -0.28 & 1.80 & 5.33 & 2.21 & 0.59 & 13.79 & -28.98 & -1.83 & -0.01 & -0.06 & 23.90 & 0.61 & 7.76 & -0.07 \\
\hline $82-1,68-73$ & 1 & 11 & -4.13 & -0.21 & 1.58 & 0.38 & -5.53 & 0.18 & 0.53 & -0.85 & -0.49 & -0.03 & -0.03 & 5.46 & 0.41 & -3.87 & 2.88 \\
\hline $82-1,68-73$ & d & 12 & -2.96 & -0.13 & 1.58 & 1.90 & -4.39 & 0.24 & 0.58 & -0.85 & -0.92 & -0.03 & -0.06 & 5.87 & 0.35 & -2.96 & 0.12 \\
\hline $82-1,90-96$ & 1 & 13 & -15.78 & -0.18 & $\begin{array}{l}1.30 \\
-4.81\end{array}$ & -0.74 & $\begin{array}{r}-12.10 \\
-12\end{array}$ & 0.49 & $\begin{array}{r}-1.73 \\
-1.73\end{array}$ & -13.84 & 4.63 & 0.02 & -0.07 & 8.54 & 0.99 & -4.24 & 16.16 \\
\hline $84-2,48-50$ & 1 & 14 & -16.10 & -0.30 & -8.82 & -0.13 & -9.65 & 0.20 & -1.32 & -15.97 & 1.16 & -0.04 & -0.05 & 13.57 & 0.35 & -7.50 & - 5.22 \\
\hline $87-1,116-123$ & i & 15 & -7.06 & -0.01 & -1.34 & 0.94 & -2.94 & 0.37 & 0.76 & -1.03 & 0.58 & -0.03 & -0.03 & 6.81 & 0.28 & -2.44 & -0.03 \\
\hline $91-1,66-70$ & 1 & 16 & -15.39 & -0.60 & -10.50 & 1.21 & -9.96 & 0.23 & -0.16 & -16.18 & 3.76 & -0.04 & -0.08 & 9.86 & 0.36 & -9.03 & 1.16 \\
\hline $91-1,66-70$ & d & 17 & 2.59 & -0.60 & 2.36 & 1.70 & -3.91 & 0.10 & 2.59 & 1.51 & -0.90 & -0.03 & -0.05 & 3.71 & 0.37 & -2.63 & 0.15 \\
\hline $94-1,132-135$ & d & 18 & -3.25 & -0.01 & 1.58 & 1.32 & -4.71 & 0.12 & 1.46 & -2.02 & 0.48 & -0.03 & -0.03 & 6.77 & 0.26 & -2.70 & 1.95 \\
\hline $95-1,140-143$ & 1 & 19 & 0.62 & 0.07 & -1.77 & 0.77 & -2.8 & 0.09 & -0.8 & -1.8 & 0.08 & -0.03 & -0.03 & 5.85 & 0.38 & -2.51 & -0.03 \\
\hline & d & 20 & -1.18 & -0.07 & -0.02 & 2.62 & -3.47 & 0.13 & & -0.19 & 0.96 & -0.03 & -0.03 & 5.31 & -0.02 & -1.22 & 0.18 \\
\hline $97-1,88-90$ & 1 & 21 & -25.03 & -0.52 & -10.76 & 0.85 & -8.37 & 0.06 & -4.58 & -2.35 & -4.31 & -0.01 & -0.08 & 17.49 & 0.83 & -5.80 & 4.12 \\
\hline $99-1,70-74$ & 1 & 22 & -16.72 & -0.39 & -7.34 & 1.56 & -1.47 & 0.13 & 0.41 & -9.89 & 1.57 & -0.03 & -0.07 & 13.15 & 0.03 & -0.16 & -0.06 \\
\hline $99-2,42-50$ & 1 & 23 & -20.01 & -0.17 & -4.23 & 2.91 & 2.74 & 0.18 & 2.33 & -16.89 & 3.54 & -0.01 & -0.07 & 13.69 & 0.11 & 5.90 & -0.12 \\
\hline $100-1,83-87$ & $\mathrm{~b}$ & 24 & -16.39 & -0.50 & -9.06 & 1.58 & -1.07 & 0.08 & -1.68 & -17.28 & 1.87 & -0.01 & -0.05 & 14.90 & -0.06 & 0.34 & 0.01 \\
\hline $101-1,134-138$ & b & 25 & -5.91 & -0.25 & -4.19 & & -4.06 & 0.10 & 2.57 & -7.17 & 3.76 & -0.00 & -0.06 & 8.71 & -0.04 & -2.01 & -0.00 \\
\hline $104-2,57-$ & l & 26 & -2.91 & -1.1 & 5.8 & 0.34 . & $\begin{array}{l}-8.92 \\
-8.92\end{array}$ & -0.09 & 0. & -1.35 & 1.6 & 0.00 & -0.12 & 6.54 & -0.03 & -9.55 & -0.12 \\
\hline & d & 2 & -3.05 & -0.06 & 5.2 & 3.89 & -6.28 & 0.01 & -1.0 & 0.74 & 0.09 & -0 & -0. & 4. & 0.00 & -3 & 0.06 \\
\hline $104-2,67-72$ & d & 28 & -5.51 & -0.3 & 3.5 & 1.49 & -6.27 & -0.03 & -0.18 & -0.49 & 0.05 & -0.03 & -0 & 6.36 & -0.03 & -5.46 & -0.06 \\
\hline $104-2,79-82$ & d & 2 & -8.3 & -0 & & 3. & -6.07 & -0.00 & 0.2 & -0.20 & -0.39 & 0. & -0.03 & 6.36 & -0.03 & -3.19 & 0.11 \\
\hline $107-1,90-92$ & 1 & 30 & -1 & -0 & -0.32 & 2.90 & -5 & 0.00 & 1.41 & 1.06 & 0.02 & -0 & -0 & 4.13 & -0.03 & -3 & 0.09 \\
\hline $111-1,41-45$ & d & 31 & -26.22 & -0.30 & & 4.48 & -7.60 & -0.09 & -0.56 & -4.39 & -0.54 & -0.01 & -0.04 & 9.40 & 0.06 & -4.09 & -0.06 \\
\hline $113-1,47-50$ & 1 & 32 & -2.47 & -0.79 & 2. & 1.16 & -5.43 & -0.02 & 2.91 & 0.74 & -0.38 & -0.03 & -0.09 & 5.13 & 0.00 & -4.86 & 0.00 \\
\hline & 1 & 3 & -21.5 & -1 & -1. & & 2. & 0.05 & -2.87 & -16.74 & & -0 & -0.12 & 16.0 & 0.09 & 5.36 & -0.06 \\
\hline & i & 34 & -7.3 & -0 & -1 & & -3 & -0 & 2.14 & -6 & & -0 & -0 & 7. & -0.04 & -3.42 & -0.06 \\
\hline & d & 35 & -9 & & -2 & & & 0 & 0. & -1 & 0. & -0 & -0. & 7. & 0.14 & -0.94 & -0.00 \\
\hline 127 & d & 36 & -2.07 & -0 & 4 & 1.35 & -5.86 & -0.05 & 2.78 & 1.29 & -0.81 & -0 & -0 & 4.4 & 0.09 & -5 & 0.09 \\
\hline $132-1,118-122$ & 1 & 37 & -4.52 & -0.70 & 1.86 & 0.20 & -4.49 & 0.00 & 2.99 & -1.39 & 0.64 & -0.03 & -0.09 & 7.05 & 0.00 & -4.78 & -0.06 \\
\hline $133-2,34-43$ & 1 & 38 & -6.66 & -0.89 & -4.88 & 1.57 & -5.11 & 0.03 & 0.04 & -6.81 & 0.74 & -0.03 & -0.09 & 8.77 & -0.04 & -4.12 & -0.04 \\
\hline & d & 39 & -0.7 & 0. & $\begin{array}{l}-1 . \\
-1 .\end{array}$ & 1.4 & -3 . & & 1. & $\begin{array}{l}0.01 \\
1.03\end{array}$ & 0.56 & -0. & -0.03 & 4.75 & 0.00 & -2.31 & -0.12 \\
\hline & 1 & 4 & -23.2 & -1 & -4 & & & & 3. & -22 . & & & -0 & 19. & & 9.68 & -0.12 \\
\hline & d & 41 & -0 & -0 & -1 & 2.92 & & & -0.34 & & -0.17 & & & & & & 0.06 \\
\hline $141-1,67-71$ & 1 & 42 & -43.06 & -0.04 & -1.94 & 8.40 & 12.62 & -0.08 & 3.34 & -28.20 & 1.40 & -0.04 & -0.02 & 19.24 & -0.01 & 22.49 & 0.01 \\
\hline
\end{tabular}

Note: See text for methods of calculation and discussion. Errors calculated from data in Tables 1-3 are given as $\pm \mathrm{g} / 100 \mathrm{~cm}^{3}$ basalt at the $95 \%$ confidence level: $\mathrm{SiO}_{2}: 10.96, \mathrm{TiO}_{2}: 0.53, \mathrm{Al}_{2} \mathrm{O}_{3}$ : 5.76, $\mathrm{Fe}_{2} \mathrm{O}_{3}: 0.42, \mathrm{FeO}: 0.89, \mathrm{MnO}: 0.41, \mathrm{MgO}: 3.06, \mathrm{CaO}: 3.17, \mathrm{Na}_{2} \mathrm{O}: 1.12, \mathrm{~K}_{2} \mathrm{O}: 0.03, \mathrm{P}_{2} \mathrm{O}_{5}: 0.16, \mathrm{Fe}_{2} \mathrm{O}_{3} \mathrm{~T}: 4.18$. Not determined for $\mathrm{H}_{2} \mathrm{O}^{+}, \mathrm{CO}_{2}$, or $\mathrm{S}$. a $\mathrm{S}$ fluxes calculated assuming $500 \mathrm{ppm} \mathrm{S}$ in unaltered basalt.

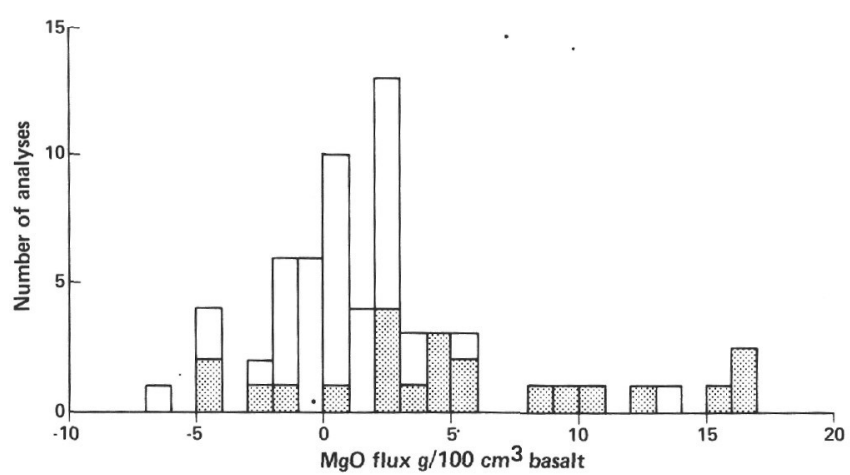

Figure 5. Histogram of $\mathrm{MgO}$ fluxes in submarine basalts. Leg 83 data from Table 4 plotted as open boxes. Recalculated data for dredged basalts from Humphris and Thompson (1978; see text) plotted as dark boxes for comparison.

tion is representative of the upper oceanic crust, then the volume of pillow basalts altered under greenschist facies conditions is very small.

The crust of Site 504 was buried by sediment relatively rapidly (Anderson et al., 1982). However, this rapid burial did not necessarily influence the hydrothermal alteration of Leg 83 basalts, since the high alteration temperatures indicate that the metamorphism occurred relatively close to the spreading axis (see discus- sions in Alt et al., this volume; Honnorez et al., this volume). Greenschist-facies parageneses may have formed near the surface of the crust close to the axis of spreading with no sediments present, followed by burial by basalt pillows and flows and eventually sediments as the crust moved away from the axis.

On the other hand, the metamorphism may have occurred slightly further off-axis (but not more than a few $\mathrm{km}$ ) under the existing $571 \mathrm{~m}$ of pillows and flows and some sediment cover. In this case it is possible that the basalt and sediment cover may have restricted fluid circulation in the deeper parts of the hole and resulted in alteration at lower water/rock ratios. However, the recovery of highly fractured and extensively recrystallized basalts from the bottom of the dike section suggests that water/rock ratios and extent of alteration were controlled more by local permeability variations in the crust than by sediment burial.

A plot of $\Delta \mathrm{CaO}$ versus $\Delta \mathrm{MgO}$ (Fig. $4 \mathrm{C}$ ) shows that Leg 83 basalts generally have not exchanged $\mathrm{Mg}$ for $\mathrm{Ca}$ on a 1:1 molar basis as seen in dredged rocks and in experimental basalt-seawater reactions at high water/rock ratios (Humphris and Thompson, 1978; summary in Mottl, 1983). Most Leg 83 basalts have gained Na (Fig. 1 and 3, Table 4), suggesting that $\mathrm{Na}$ uptake may account for much of the $\mathrm{Ca}$ loss in excess of the $\mathrm{Mg}$ up- 
take shown in Figure 4C. However, on a plot of $\triangle \mathrm{CaO}$ versus $\Delta \mathrm{MgO}+\mathrm{Na}_{2} \mathrm{O}$ (moles $/ 100 \mathrm{~cm}^{3}$ basalt; not shown) it is seen that although samples that have lost large amounts of $\mathrm{CaO}$ lie further to the right than in Figure $4 \mathrm{C}$, they still fall well below the 1:1 exchange line. This is most likely due to the decreased densities and net loss of material from many samples.

\section{Water/Rock Ratios}

In basalt-seawater reactions the water/rock ratio is simply defined as the mass of water relative to the mass of basalt initially present. Experiments indicate that $\mathrm{Na}$ is taken up by the basalt at water/rock mass ratios less than about 10, whereas it is leached from the rocks at higher ratios (summary in Mottl, 1983). Based on this observation, the general Na-enrichments of Leg 83 basalts would suggest alteration at water/rock mass ratios (as defined previously) less than about 10 . However, water/rock mass ratios calculated on the assumption that all $\mathrm{Mg}$ was extracted from unaltered seawater $(1280 \mathrm{ppm}$ $\mathrm{Mg}$ ) that reacted with rocks of density $2.90 \mathrm{~g} / \mathrm{cm}^{3}$ to produce the $\mathrm{Mg}$ fluxes and densities in Tables 4 and 1, respectively, range up to a maximum value of 22 for the altered glassy pillow rim (Analysis 10). All other values are less than 9, and most fall in the range from -3 to +5 , averaging +1.38 . Actual water/rock ratios were certainly greater than were calculated using $\mathrm{Mg}$ uptake, since the hydrated nature of the rocks prohibits negative values, and alteration is interpreted to have occurred by reaction of basalts with at least partly $\mathrm{Mg}$-depleted solutions (Alt et al., this volume). These examples point out some of the difficulties associated with calculating water/rock ratios for natural systems.

\section{Crustal Fluxes}

It is not the purpose of this discussion to quantitatively characterize bulk crustal chemical changes arising from hydrothermal alteration, but, rather, to comment on the significance of Leg 83 samples. Humphris and Thompson (1978) calculated seawater-crustal fluxes arising from hydrothermal alteration of the crust using as variables $\mathrm{Mg}$ uptake of basalt and volume of rock altered. From an assumed average uptake rate of $5 \mathrm{~g}$ $\mathrm{MgO} / 100 \mathrm{~cm}^{3}$ basalt and a depth of hydrothermal penetration of $2-5 \mathrm{~km}$, it was calculated that $50-20 \%$ of the available crust must be altered to account for the excess river $\mathrm{Mg}$ input to the oceans. If it is assumed that Hole 504B samples are representative of the upper oceanic crust (i.e., only a small volume of pillow basalts contain greenschist-facies parageneses), then sample sets consisting only of altered pillow basalts are biased. Also, rocks dredged from fault scarps may have been altered at high water/rock ratios localized along fractures in the crust. The $\mathrm{MgO}$ gains for Leg 83 basalts average +0.8 $\mathrm{g} / 100 \mathrm{~cm}^{3}$. If we use an uptake value of $1 \mathrm{~g} \mathrm{MgO} / 100$ $\mathrm{cm}^{3}$ basalt and otherwise make the same assumptions as in the previous calculation, we arrive at an unrealistic estimate of the amount of crust that must be altered to account for the excess river $\mathrm{Mg}$ flux $(250-100 \%$ of the available crust). Based on submarine hot spring chemistry and heat flow data, Mottl (1983) suggested that $\mathrm{Mg}$ uptake by the oceanic crust in high temperature submarine hydrothermal systems may not be an adequate sink for solving the $\mathrm{Mg}$ mass balance in the oceans.

The gains and losses in Table 4 do not take into account the redistribution of material lost from the basalts and the uptake of seawater components into vein minerals, which can have a significant effect on net crustal fluxes (Staudigel and Hart, 1983; Alt, 1982). The abundant Ca-rich zeolites occurring in veins indicate that much of the Ca lost by the basalts is retained in the crust as vein minerals. By the same token, much of the silica released by the basalts must be retained in the crust in the frequent quartz veins observed in the transition zone, and $\mathrm{Mg}$ uptake should also be increased by taking into account the abundant $\mathrm{Mg}$-rich clay minerals in veins and breccias.

Since recovery of basalts on Leg 83 averaged only about $15 \%$, it is possible that the rocks recovered from the hole are not representative of the crust and that more extensively altered portions were not recovered. Also, the distribution of alteration minerals and extent of alteration in the Leg 83 basalts is heterogeneous on a scale ranging from centimeters to tens or hundreds of meters. Localized zones of highly fractured and extensively altered basalt such as those recovered from the bottom of the drilled dike section also have been observed in ophiolites (e.g., Elthon, 1981; Rosencrantz, 1983). This sort of heterogeneity, if it is typical of altered oceanic crust, should have a significant effect on calculation of crustal chemical fluxes from whole-rock data.

\section{CONCLUSIONS}

Alteration of Leg 83 basalts is characterized by nonequilibrium and is heterogeneous on a scale of centimeters to tens or hundreds of meters. The basalts exhibit trends towards losses of $\mathrm{SiO}_{2}, \mathrm{CaO}, \mathrm{TiO}_{2}$; decreases in density; gains of $\mathrm{MnO}, \mathrm{Na}_{2} \mathrm{O}, \mathrm{CO}_{2}, \mathrm{H}_{2} \mathrm{O}^{+}, \mathrm{S}$; slight gains of $\mathrm{MgO}$; increased oxidation of $\mathrm{Fe}$; and variable changes in $\mathrm{Al}_{2} \mathrm{O}_{3}$. Some mobility of rare earth elements (REE) also occurred, especially the light REE and $\mathrm{Eu}$. The basalts have lost $\mathrm{Ca}$ in excess of $\mathrm{Mg}+\mathrm{Na}$ gains. Variations in chemical trends are due to differing water/rock ratios, substrate control of secondary mineralogy, and superimposition of greenschist- and zeolitefacies mineralogies. Zeolitization resulted in uptake of $\mathrm{Ca}$ and $\mathrm{H}_{2} \mathrm{O}$ and losses of $\mathrm{Si}, \mathrm{Al}$, and $\mathrm{Na}$. These effects are different from the $\mathrm{Na}$ uptake observed in other altered basalts from the seafloor attributed to the zeolite facies and are probably due to higher temperatures of alteration of Leg 83 basalts.

Basalts from the transition zone are enriched in Mn, $\mathrm{S}$, and $\mathrm{CO}_{2}$ relative to the pillow and dike sections, and contain a metal-sulfide-rich stockwork zone, suggesting that they were at one time located within or near a hydrothermal upflow zone. Samples from the bottom of the dike section are extensively fractured and recrystallized indicating that alteration was significantly affected by local variations in permeability.

Calculation of crustal fluxes from bulk-rock chemical data is complicated by the heterogeneity of alter- 
ation effects. Individual bulk-rock $\mathrm{MgO}$ fluxes are smaller than those from dredged basalts. If we take into account vein minerals, we may significantly increase the estimates of $\mathrm{Mg}$ uptake by the crust and retain much of the $\mathrm{Ca}$ and $\mathrm{Si}$ lost by the basalts.

\section{ACKNOWLEDGMENTS}

J. C. Alt thanks Jose Honnorez for the opportunity to participate on Leg 83 and for many helpful comments and discussions. J.C.A's contribution was supported by NSF Grant OCE 81-17698 to J. Honnorez.

An earlier version of the manuscript benefited from reviews by Paul Robinson and Hubert Staudigel. This chapter is a contribution from the Rosenstiel School of Marine and Atmospheric Science, University of Miami.

\section{REFERENCES}

Abbey, S., 1980. Studies in "standard samples" for use in the general analysis of silicate rocks and minerals. Geostand. Newsl., IV (no. 2):163-190.

1982. An evaluation of USGS III. Geostand. Newsl., VI (no. 1):47-76.

Alt, J. C., 1982. Alteration of the upper oceanic crust, DSDP Site 417, [M.S. thesis]. University of Miami.

Anderson, R. N., Honnorez, J., Becker, K., Adamson, A. C., Alt, J. C., Emmermann, R., Kempton, P. D., Kinoshita, H., Laverne, C., Mottl, M. J., and Newmark, R. L., 1982. DSDP Hole 504B, the first reference section over $1 \mathrm{~km}$ through layer 2 of the oceanic crust. Nature, 300:589-594.

Cann, J. R., 1969. Spilites from the Carlsberg Ridge, Indian Ocean. $J$. Petrol., 10:1-19.

1981. Basalts from the ocean floor. In Emiliani, C. (Ed.), The Oceanic Lithosphere The Sea (Vol. 7): New York, (John Wiley and Sons), 363-390.

Cann, J. R., Langseth, M. G., Honnorez, J., Von Herzen, R. P., White, S. M., et al., 1983. Init. Repts. DSDP, 69: Washington (U.S. Govt. Printing Office).

Coombs, D. S., 1971. Present status of the zeolite facies: Molecular Sieve Zeolites I: New York (Am. Chem. Soc.), pp. 317-327.

Edmond, J. M., Measures, C. McDuff, R. E., Chan, L. J., Collier, R., Grant, B., Gordon, L. I., and Corliss, J. B., 1979. Ridge crest hydrothermal activity and the balances of the major and minor elements in the ocean: The Galapagos data. Earth Planet. Sci. Lett., 46:1-18.

Elthon, D., 1981. Metamorphism in oceanic spreading centers. In Emiliani, C. (Ed.), The Oceanic Lithosphere The Sea. (Vol. 7): New York, (John Wiley and Sons), pp. 285-304.

Gladney, E. S., 1983. A compilation of elemental concentrations in II United States Geological Survey rock standards. Geostand. Newsl., VII (no. 1):3-226.

Govindaraju, K., 1980. Report on three GIT-IWG rock reference samples: anorthosite from Greenland, AN-G; basalte d'Essy-la-Côte, BE-N; granite de Beauvoir, MA-N. Geostand. Newsl., IV (no. 1): 49-138.

Honnorez, J., Laverne, C., Hubberten, H.-W., Emmermann, R., and Muehlenbachs, K., 1983. Alteration processes of Layer 2 basalts from Deep Sea Drilling Project Hole 504B, Costa Rica Rift. In Cann, J. R., Honnorez, J., Langseth, M. G., Von Herzen, R. P., White, S. M., et al., Init. Repts. DSDP, 70: Washington (U.S. Govt. Printing Office), 509-546.

Hubberten, H.-W., Emmermann, R., and Puchelt, H., 1983. Geochemistry of basalts from Costa Rica Rift Sites 504 and 505 (Deep Sea Drilling Project Legs 69 and 70). In Cann, J. R., Honnorez, J.,
Langseth, M. G., Von Herzen, R. P., White, S. M., et al., Init. Repts. DSDP, 69: Washington (U.S. Govt. Printing Office), 791-804.

Humphris, S. E., Morrison, M. A., and Thompson, R. N., 1978. Influence of rock crystallization history upon subsequent Lanthanide mobility during hydrothermal alteration of basalts. Chem. Geol., 23:125-137.

Humphris, S. E., and Thompson, G., 1978. Hydrothermal alteration of oceanic basalts by seawater. Geochim. Cosmochim. Acta, 43: $107-125$.

Karato, S., 1983. Physical properties of basalts from Deep Sea Drilling Project Hole 504B, Costa Rica Rift. In Cann, J. R. Honnorez, J., Langseth, M. G., Von Herzen, R. P., White, S. M., et al., Init. Repts. DSDP, 69: Washington (U.S. Govt. Printing Office), 687-696.

Ludden, J. N., and Thompson, G., 1979. An evaluation of the behavior of the rare earth elements during the weathering of seafloor basalt. Earth Planet. Sci. Lett., 43:85-92.

Menzies, M., Blanchard, D., and Jacobs, J., 1977. Rare earth and trace element geochemistry of the Point Sal Ophiolite, California. Earth Planet. Sci. Lett., 37:203-215.

Miyashiro, A., Shido, F., and Ewing, M., 1971. Metamorphism in the Mid-Atlantic Ridge near $24^{\circ}$ and $2-30^{\circ}$ N. Philos. Trans. R. Soc. London, Ser. A., 268:589-604.

Mottl, M. J., 1983, Metabasalts, axial hot springs, and the structure of hydrothermal systems at Mid-Ocean Ridges. Geol. Soc. Am. Bull., 94:161-180.

Natland, J. H., Adamson, A. C., Laverne, C., Melson, W. G., and O'Hearn, T. A., 1983. A compositionally nearly steady-state magma chamber at the Costa Rica Rift: Evidence from basalt glass and mineral data, Deep Sea Drilling Project Sites 501, 504, and 505. In Cann, J. R., Honnorez, J., Langseth, M. G., Von Herzen, R. P., White, S. M., et al., Init. Repts. DSDP, 69: Washington (U.S. Govt. Printing Office), 811-858.

Reed, M. H., 1983. Seawater-basalt reaction and the origin of greenstones and related ore deposits. Econ. Geol. 78:466-485.

Rosencrantz, E., 1983. The structure of sheeted dikes and associated rocks in North Arm massif, Bay of Islands ophiolite complex, and the intrusive process at oceanic spreading centers. Can. J. Earth Sci., 20:787-801.

Seyfried, W. E., and Bishoff, J. L., 1979. Low temperature basalt alteration by seawater: an experimental study at 70 and $150^{\circ} \mathrm{C}$. Geochim. Cosmochim. Acta, 43:1937-1947.

1981. Experimental seawater-basalt interaction at $300^{\circ} \mathrm{C}$, 500 bars, chemical exchange, secondary mineral formation, and implications for the transport of heavy metals. Geochim. Cosmochim. Acta, 45:135-147.

Seyfried, W. E., Mottl, M. J., and Bischoff, J. L., 1978. Seawater/basalt ratio effects on the chemistry and mineralogy of spilites from the ocean floor. Nature, 275:211-213.

Shido, F., Miyashiro, A., and Ewing, M., 1974. Compositional variation in pillow lavas from the Mid-Atlantic Ridge. Mar. Geol., 16: 177-190.

Staudigel, H., Bryan, W. B., and Thompson, G., 1979. Chemical variation in glass-whole rock pairs from individual cooling units in Holes 417D and 418A. In Donnelly, T., Francheteau, J., Bryan, W. B., Robinson, P., Flower, M., Salisbury, M., et al., Init. Repts. DSDP, 51, 52, 53, Pt. 2: Washington (U.S. Govt. Printing Office), 977-986.

Staudigel, H., and Hart, S., 1983. Alteration of basaltic glass: Mechanisms and significance for the oceanic crust-seawater budget. Geochim. Cosmochim. Acta, 47:337-350.

Date of Initial Receipt: 15 April 1983

Date of Acceptance: 8 November 1983 